\title{
Synaptic Structural Complexity as a Factor Enhancing Probability of Calcium-Mediated Transmitter Release
}

\author{
ROBIN L. COOPER, JAMES L. WINSLOW, C. K. GOVIND, AND HAROLD L. ATWOOD \\ Department of Physiology, Medical Research Council Group on Nerve Cells and Synapses; Institute of Biomedical \\ Engineering; and Life Sciences, Scarborough College, University of Toronto, Toronto M5S 1A8, Canada
}

\section{SUMMARY AND CONCLUSIONS}

1. In a model synaptic system, the excitatory neuromuscular junction of the freshwater crayfish, the nerve terminals possess synapses that vary in structural complexity, with numbers of active zones ranging from zero to five. Active zones on individual synapses show a wide range of separation distances. We tested the hypothesis that two active zones of a single synapse in close proximity can enhance the localized increase in free calcium ion concentration, thus enhancing the probability of neurotransmission at that synapse. We evaluated the increase in calcium ion concentration as a function of distance between adjacent active zones.

2 . To test this hypothesis, a reaction-diffusion model for $\mathrm{Ca}^{2+}$ entering the presynaptic terminals was used. This test was used because 1 ) present measurement techniques are inadequate to resolve quantitatively the highly localized, transient calcium microdomains at synaptic active zones; and 2) there is presently no suitable preparation for physiological recording from isolated synapses with varying distances between active zones. Included in the model were intracellular buffer and a typical distribution of voltage-activated $\mathrm{Ca}^{2+}$ channels for an active zone, estimated from freeze-fracture micrographs.

3. The model indicated that localized $\mathrm{Ca}^{2+}$ clouds from discrete active zones can overlap to create spatial enhancement of $\mathrm{Ca}^{2+}$ concentration. The degree of interaction between two active zones depends on the distance between them. When two typical active zones are separated by $\leq 200 \mathrm{~nm}$, the maximum intracellular $\mathrm{Ca}^{2+}$ concentration $\left(\left[\mathrm{Ca}^{2+}\right]_{i}\right)$ is greater at 1$)$ the midpoint between them, and 2 ) the center of each one, than at the corresponding positions for a single isolated active zone. Enhanced $\left[\mathrm{Ca}^{2+}\right]_{\mathrm{i}}$ at the edge of the active zone where "docked" synaptic vesicles occur would be expected to have an effect on transmitter release.

4. When the model includes no intracellular buffer, the increase in $\left[\mathrm{Ca}^{2+}\right]_{\mathrm{i}}$ is a linear function of calcium channel current, but is a nonlinear function of the number of conducting calcium channels in an active zone. With immobile buffer included, the increase in $\left[\mathrm{Ca}^{2+}\right]_{\mathrm{i}}$ is nonlinear with respect to both channel current and number of conducting channels.

5 . Inclusion of immobile buffer in the model provides "released" residual calcium that slowly accumulates during a train of current pulses. Released residual calcium accumulates more rapidly at paired active zones separated by $\leq 200 \mathrm{~nm}$ than at single isolated active zones.

6 . We propose that the probability of release is enhanced at synapses with closely associated active zones. Synapses of this type ("complex" synapses) could be selectively recruited when the neuron is active at low frequencies. At higher frequencies of neuronal activity, more distant active zones may interact and acquire a greater probability of releasing quanta. This would provide the nerve terminal with one component of a mechanism for frequency facilitation, because the number of quanta released by the terminal as a whole would increase with frequency. Thus variation in synaptic complexity in a nerve terminal provides a mechanism for short-term plasticity of transmitter release.

\section{INTR O D UCTION}

Depolarization-induced $\mathrm{Ca}^{2+}$ entry through voltage-sensitive calcium channels of presynaptic terminals is known to be a key factor for the induction of neurotransmitter release. Katz and Miledi (1967, 1968) demonstrated that altering the concentration of external $\mathrm{Ca}^{2+}$ affected the amount of transmitter released by nerve terminal depolarization, and that $\mathrm{Ca}^{2+}$ ion influx is essential for evoked release. Direct evidence for a positive relationship between $\mathrm{Ca}^{2+}$ influx and the magnitude of neurotransmitter secretion has becn shown in studies of the giant synapse in squid (Augustine and Charlton 1986; Augustine et al. 1985; Llinas et al. 1981; for reviews, see Augustine et al. 1987, 1991; Sugimori et al. 1994; Zucker et al. 1991).

Current anatomic, physiological, and theoretical findings indicate that at several different types of nerve terminals, calcium channels are clustered close to the site at which vesicles release their contents (Issa and Hudspeth 1994; Parsegian 1977; Pumplin et al. 1981; Stanley 1993). Freezefracture photomicrographs of the presynaptic extracellular surfaces of various synapses (Dreyer et al. 1973; Govind et al. 1994; Heuser et al. 1974; Propst and Ko 1987; Walrond and Reese 1985) show clusters of large intramembranous particles in close association with vesicle fusion points, indicated by large pits in freeze-fracture photomicrographs and by the presence of omega-shaped profiles in transmission electron micrographs. Where synaptic vesicles cluster near the presynaptic thickening, transmission electron micrographs show a localized accumulation of electron-dense material, the dense body or presynaptic dense bar, which assumes different forms in various nerve terminals. Such structures are commonly seen at synapses of crustacean ncuromuscular junctions (Jahromi and Atwood 1974; Walrond et al. 1993) and at numerous other synapses, including vertebrate cochlear hair cells (rat: Smith 1961; cat: Spoendlin 1968), frog papillary hair cells (Issa and Hudspeth 1994), retinal receptor cells (Dowling 1968), squirrel monkey macula (Engstrom et al. 1972), and rat spinal cord axodendritic synapses (Peters et al. 1970). Although the composition of the dense body is not fully clucidated, it appears to be a reliable indicator of the occurrence of closely associated presynaptic large intramembraneous particles. Taken together, this constellation of microanatomic features 
is characteristic of synaptic active zones (AZs) (Couteaux 1970; Couteaux and Pécot-Dechavassine 1974; Pappas and Waxman 1972).

Pumplin et al. (1981) postulated that the large intramembraneous particles of the AZs are calcium channels that are localized near release sites. In addition to these voltageactivated calcium $\left(\mathrm{Ca}_{\mathrm{V}}\right)$ channels, there are also calciumactivated potassium $\left(\mathrm{K}_{\mathrm{Ca}}\right)$ channels in the $\mathrm{AZ}$. Application of labeled toxins to $\mathrm{Ca}_{\mathrm{v}}$ channels (Cohen et al. 1991; Robitaille et al. 1990) and to $\mathrm{K}_{\mathrm{Ca}}$ channels (Robitaille et al. 1993) showed that both of these channel types are clustered in AZs of frog motor nerve terminals. Physiological recordings of calcium currents with loose-patch-clamp techniques are supportive of $\mathrm{Ca}_{v}$ channel clustering near release sites in the frog sacculus hair cells (Roberts et al. 1990, 1991) and in the ends of neurites that give rise to presynaptic terminals of synaptically coupled cultured neurons (Cooper et al. 1993 ). At the crayfish neuromuscular junction, the presence of $\mathrm{Ca}_{\mathrm{V}}$ and $\mathrm{K}_{\mathrm{Ca}}$ currents has been demonstrated with electrophysiological methods (Blundon et al. 1993, 1995; Wright et al. 1994). Calcium imaging with $\mathrm{Ca}^{2+}$-sensitive dyes at the giant synapse of squid suggests that $\mathrm{Ca}^{2+}$ entry is localized along the terminal where AZs are present (Smith et al. 1993). This cumulative evidence supports the concept that $\mathrm{Ca}_{\mathrm{V}}$ and $\mathrm{K}_{\mathrm{Ca}}$ channels are clustered in the presynaptic nerve terminal membrane. Within the AZs of frog saccular hair cells, Roberts et al. (1990) estimated that the ratio of $\mathrm{Ca}_{\mathrm{v}}$ to $\mathrm{K}_{\mathrm{Ca}}$ channels is two to one.

In the current study, we pursue further the hypothesis that AZ microanatomy may be linked to transmission characteristics of individual synapses, using the well-studied motor axon of the opener muscle in the crayfish leg (Dudel and Kuffler 1961). This tonic motor axon, which constitutes the entire excitatory motor supply of the muscle, branches into a series of varicose terminals that innervate all the muscle fibers (Atwood et al. 1994; Florey and Cahill 1982). Each varicose terminal possesses 10-40 small, discrete synapses, each endowed with zero to five AZs (Govind et al. 1994; Jahromi and Atwood 1974; Wojtowicz et al. 1994). The majority of synapses have zero or one AZs, but some, with two or more, are structurally more complex. We hypothesize that these more complex synapses have a higher probability of releasing neurotransmitter when the motor axon is active at low frequencics (Wojtowicz et al. 1994). Because a single $\mathrm{AZ}$ is thought to produce a $\mathrm{Ca}^{2+}$ cloud or domain, two adjacent AZs could produce overlapping $\mathrm{Ca}^{2+}$ clouds. This effect would enhance the intracellular concentration of $\mathrm{Ca}^{2+}$ $\left(\left[\mathrm{Ca}^{2+}\right]_{\mathrm{i}}\right)$, particularly at the edges of an AZ, where synaptic vesicles are seen to be docked and released in electron micrographs (Govind et al. 1994). More widely separated AZs in a synapse would be less likely to interact. Thus the probability of transmitter release may be influenced by the structural complexity of the individual synapse.

In the present study we investigated the hypothesis that ion channels of closely adjacent presynaptic AZs produce calcium concentration responses that overlap in space to enhance the probability of neurotransmitter relcasc. To test the hypothesis, we adopted a modeling approach, because present measurement techniques are not adequate to resolve the highly localized, transient calcium microdomains postulated to occur at individual $\mathrm{AZs}$ within a synapse during neurotransmission, although some of their general characteristics have been demonstrated with optical methods in the specialized giant synapse of the squid (Llinas et al. 1992). Also, there is presently no suitable preparation for physiological recording from isolated synapses with varying distances between AZs.

The model combines a three-dimensional reaction-diffusion model (Winslow et al. 1994b) and detailed structural observations from electron micrographs. Calcium buffering, which is known to influence the $\mathrm{Ca}^{2+}$ signal (Nowicky and Pinter 1993; Roberts 1994; Winslow 1995; Winslow et al. 1994b; Zhou and Neher 1993), was included in the model.

Preliminary results of this work have been reported in abstracts (Cooper et al. 1994; Winslow et al. 1994a).

\section{METHODS}

\section{Biological preparation}

Specimens of the southern crayfish, Procambarus clarkii, were purchased from Atchafalaya Biological Supply (Raceland, LA) and held in fresh water aquaria at $15^{\circ} \mathrm{C}$ in our laboratory in Toronto. The carapace length of these animals ranged from 2 to $6 \mathrm{~cm}$. Motor nerve terminals of the excitatory axon to the opener muscle in the first and second walking legs were used to calculate the two essential parameters of this study, viz., the distance between AZs within a synapse and the distribution of putative calcium channels within an AZ.

To calculate the distance between adjacent AZs, we used specimens from a previous study (Cooper et al. 1995a) in which macropatch recordings of quantal release of transmitter were made from three nerve terminal varicosities visualized with a fluorescent dye and subsequently serially thin-sectioned for electron microscopy. Each of these three varicosities had 30-40 synapses (Fig. 1 ), endowed with variable numbers of AZs. An AZ was identified by the presence of a dense body surrounded by a halo of clear vesicles on the presynaptic membrane (Fig. 2). Measurements of the separations of adjacent dense bodies (Fig. 3) were made in one of two ways, depending on the location of the dense bodies. When adjacent dense bodies were seen in a single thin section either in tangential or transverse views, we could measure the distance between the midpoints of the dense bodies. When adjacent dense bodies appeared on separate transverse thin sections within a synapse, as happened in the majority of cases, the distances were measured from the two-dimensional serial reconstruction of these synapses. Again, distances were measured between the midpoints of two adjacent dense bodies (Atwood and Cooper 1996). The midpoint of a dense body traversing two thin sections was assumed to be between the two sections.

A representative distribution of putative calcium channels (represented by intramembranous particles on the $P$ face of the nerve terminal) was derived from several specimens freeze-fractured according to techniques described previously (Govind et al. 1994). The freeze-fractured replicas were examined with the electron microscope and regions of interest containing synapses were photographed. Micrographs with a final magnification of $\times 80,000$ were used to determine the dimensions of an $\mathrm{AZ}$ and the number and distribution of large particles within it. Fracturing the nerve terminal membrane along its lipid bilayer exposes the complementary inner or $\mathrm{P}$ face and outer or $\mathrm{E}$ face leaflets. In longitudinal fractures of the nerve terminal membrane ( $E$ face), synapses appear as depressions of varying size and shape, in which AZs are represented by several small protrusions indicating vesicles fused to the membrane (Fig. 4). In the opposite $\mathrm{P}$ face, synapses appear as gently elevated plateaus, relatively free of particles (Fig. 5). Within the synaptic plateau, an AZ represented by a small circular depres- 


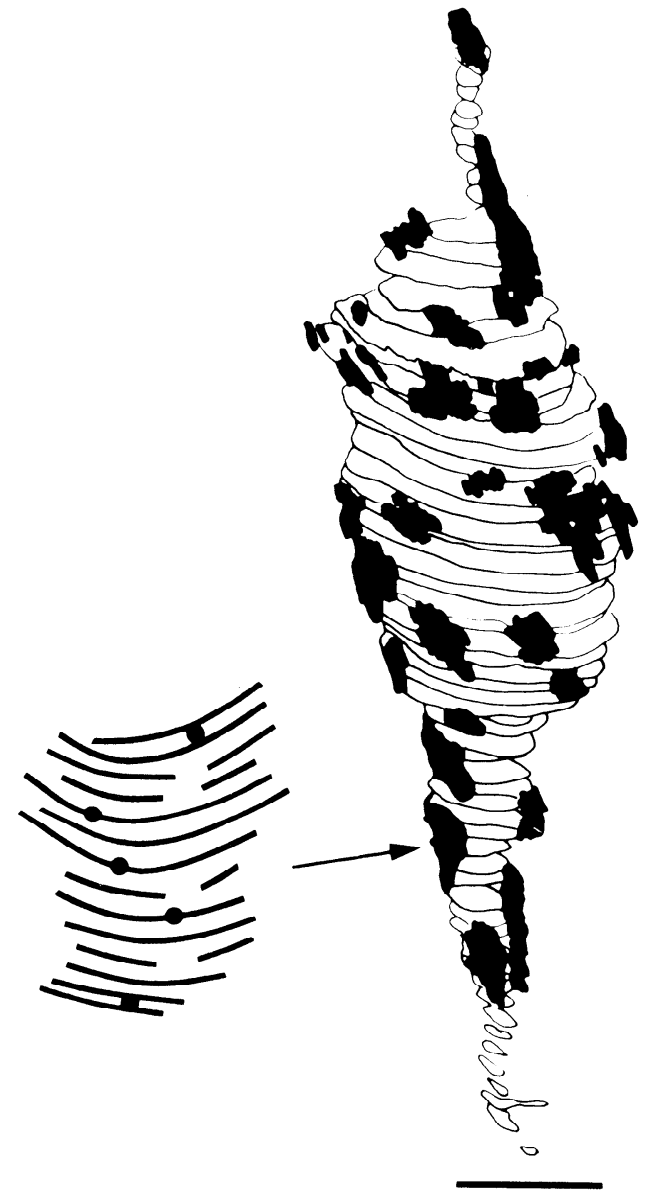

FIG. 1. Reconstructed varicosity of an excitatory nerve terminal in the crayfish opener muscle from which recordings were made. The outline of every 3rd section plane is shown for the varicosity, whereas all the visible surface is shown for the synapse. Shaded patches: different individual synapses. Inset: in face view, a representative reconstructed synapse and the positions of 5 active zones (AZs). The center of the presynaptic dense bar was taken as the center of the presynaptic AZ. Scale bar: $2 \mu \mathrm{m}$. Inset: 0.5 $\mu \mathrm{m}$.

sion encloses a cluster of large particles and a few surrounding pits. These pits represent fused vesicles and the large particles represent ion channels (Govind et al. 1994; Heuser and Reese 1973; Walrond et al. 1993), of which the majority are presumed to be $\mathrm{Ca}_{\mathrm{V}}$ channels and a minority $\mathrm{K}_{\mathrm{Ca}}$ channels (Roberts et al. 1990 ). The region immediately surrounding the $A Z$ is devoid of particles and relatively smooth; we have defined the inner perimeter of this smooth annular region as the boundary of the AZ. A typical AZ is approximately symmetrical, with a diameter of $\sim 160 \mathrm{~nm}$ (Fig. 5). In the replica illustrated (Fig. 4) there are four synapses that contain pairs of AZs in close association (A, $348 \mathrm{~nm} ; \mathrm{B}, 344$ $\mathrm{nm}$; C, $226 \mathrm{~nm}$; D, $235 \mathrm{~nm}$ ), and three synapses with single AZs.

\section{Computational preparation}

LOCATION OF CALCIUM CHANNELS IN $\Lambda \mathrm{N} \Lambda \mathrm{Z}$. The number and location of ion channels in an AZ were estimated from a representative $\mathrm{P}$ face view (Fig. $5 \Lambda$ ). This was video digitized with the use of an instrumentation video camera (NC-70, DageMTI, Michigan City, IN) and a Win-TV board (Hauppauge Computer Works, Hauppauge, NY) on a personal computer with a program running under DOS written by one of us (J. L. Winslow). The digitized images were transferred to a Silicon Graphics Indigo computer (Silicon Graphics, Mountain View, CA) where the scale bar, an outline of the AZ, and each of the individual intramembraneous particles (the putative $\mathrm{Ca}_{\mathrm{V}}$ and $\mathrm{K}_{\mathrm{Ca}}$ channels) were traced (making no distinction for size) with the use of a program written by one of us (Winslow et al. 1987). Figure $5 B$ shows the results of these steps.

Locations of $\mathrm{Ca}_{\mathrm{v}}$ channels in two separated representative AZs were computed. To estimate the fraction of $A Z$ intramembraneous particles that are $\mathrm{Ca}_{V}$ channels rather than $\mathrm{K}_{\mathrm{Ca}}$ channels, we used the frog saccular hair cell data of Roberts et al. (1990). From patch-clamp and whole cell recordings of whole cell $\mathrm{K}^{+}$current, the estimated ratio of $\mathrm{Ca}_{\mathrm{V}}$ to $\mathrm{K}_{\mathrm{Ca}}$ channels is two to one. Assuming the same ratio for the crayfish terminals, we randomly removed every third traced particle, leaving only the putative outlined $\mathrm{Ca}_{\mathrm{V}}$ channels. The center of each channel was determined from the averaged $X-Y$ coordinates of the small closed polygon outlining the channel. The centroid of the AZ was defined as the centroid of its traced outline (delineated by the inner perimeter of the surrounding smooth annular region). The locations of the channel centers were calculated with respect to the centroid of the $A Z$ and used as $\mathrm{Ca}_{\mathrm{V}}$ channel locations for the representative $\mathrm{AZ}$.

The coordinates of the $C a_{V}$ channels in two adjacent AZs were computed by separating the centroids of two copies of the representative set of channels by a fixed distance (AZ separation distance), then recomputing the centroid coordinates of each channel. The origin of the coordinate system was set at the midpoint of the line between the centroids of the two shifted AZs, designated as location 0 in the concentration versus $X-Y$ plots (Figs. 9-11). A rectangular grid of $N_{\mathrm{x}} \times N_{\mathrm{y}}$ of squares, each $\Delta x-\Delta y-20 \mathrm{~nm}$ on a side, was superimposed on the channel locations. The channel coordinates were converted to grid box indexes $(i, j)$ relative to the grid box centered at the origin. This list of grid box indexes provided channel locations for the reaction-diffusion simulation program. The channel locations are shown in the top grids of Figs. 6,9 , and 11 .

MODEL FOR CALCIUM AT AZS. To calculate the fast concentration changes in ionized calcium near the intracellular face of the $\Lambda Z$ s, we used a three-dimensional reaction-diffusion model similar to that of Winslow et al. (1994b). Diffusible ionic calcium, $\mathrm{Ca}^{2+}$, reacts with nondiffusible buffer in axoplasm, $A$, to form nondiffusible product, $Q \equiv C a A$. Similarly, $\mathrm{Ca}^{2+}$ may react with diffusible buffer, $B$, to form diffusible product, $P=C a B$. Because the current study was designed to investigate interaction of AZs, rather than effects of buffers, we set $[B]_{i}=0$ (Winslow et al. 1994b). We ignore $\mathrm{Ca}^{2+}$ pumps and exchangers because they operate on a slower time scale than we investigate here (DiPolo and Beauge 1990; Garrahan and Rega 1990; Muallem 1990; Reeves 1990). The initial resting value of $\left[\mathrm{Ca}^{2+}\right]_{\mathrm{i}}, \mathrm{C}_{0}=0.1 \mu \mathrm{M}$, is the equilibrium value established by the $\mathrm{Ca}^{2+}$ pumps on and within the whole cell including the calcium buffers (Winslow et al. 1994b; Yamada and Zucker 1992).

We use $t(\mathrm{~ms})$ for time and $C, A$, and $Q(\mathrm{M})$ for concentrations of diffusible calcium, nondiffusible buffer, and nondiffusible product, respectively. The diffusion coefficient of $\mathrm{Ca}^{2+}$ is $D_{\mathrm{Ca}}\left(\mathrm{cm}^{2} / \mathrm{ms}\right)$. The forward and backward rate constants for $\mathrm{Ca}^{2+}+A \rightleftarrows Q$ are, respectively, $k_{\mathrm{A}}^{+}(\mathrm{M} / \mathrm{ms})$ and $k_{\mathrm{A}}^{-}\left(\mathrm{ms}^{-1}\right)$, with disassociation constant $K_{\mathrm{D}}^{\mathrm{A}}=k_{\Lambda}^{-} / k_{\Lambda}^{+}$.

Within a presynaptic region of interest, $\Omega$, the rate of change of calcium concentration with respect to time, $\partial C / \partial t$, is minus the removal rate of calcium due to the binding of calcium with nondiffusible buffer, $-k_{\mathrm{A}}^{+} C A$, plus the arrival rate of calcium due to the unbinding of calcium from nondiffusible product, $k_{\mathrm{A}}^{-} Q$, plus the arrival rate of calcium duc to diffusion into the region. Similar equations hold for the other species. In a region with no influx from a calcium channel, the appropriate equations in rectangular coordinates are 

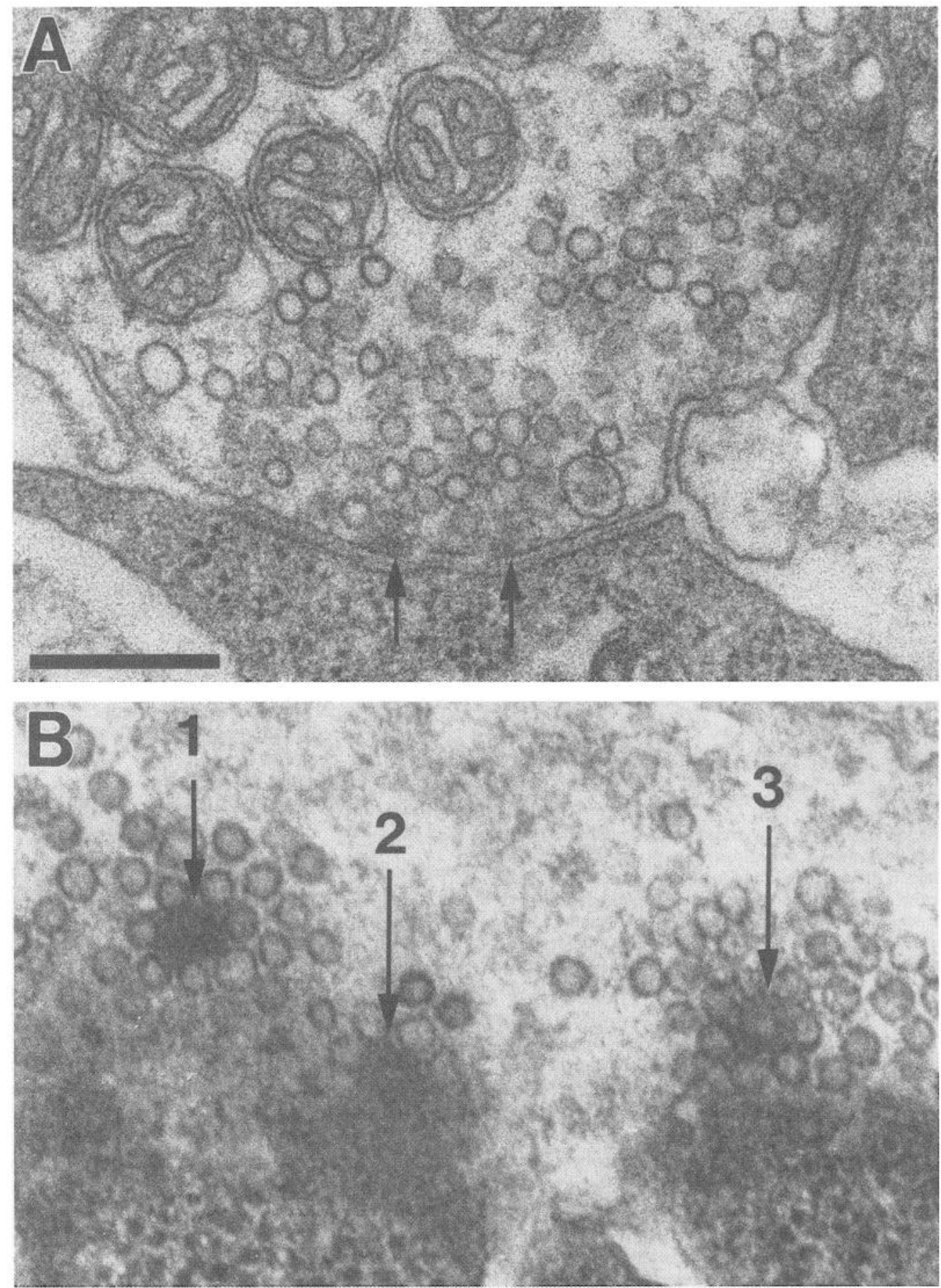

FIG. 2. A: thin section of an excitatory nerve terminal in the crayfish opener muscle showing a synaptic contact with 2 adjacent dense bars $(\downarrow)$ each abutted by an omega-shaped figure indicative of vesicle exocytosis. $B$ : face view of a synapse showing $3 \mathrm{AZs}$ (numbered 1-3), each with a cluster of vesicles. The distance between AZs 1 and 2 is $179 \mathrm{~nm}$, and the distance between AZs 2 and 3 is $283 \mathrm{~nm}$. Scale bar: $A, 0.279 \mu \mathrm{m} ; B, 0.189 \mu \mathrm{m}$.

$$
\begin{aligned}
& \frac{\partial C}{\partial t}=-k_{\mathrm{A}}^{+} C A+k_{\mathrm{A}}^{-} Q+D_{\mathrm{Ca}}\left(\frac{\partial^{2} C}{\partial x^{2}}+\frac{\partial^{2} C}{\partial y^{2}}+\frac{\partial^{2} C}{\partial z^{2}}\right) \\
& \frac{\partial A}{\partial t}=-k_{\mathrm{A}}^{+} C A+k_{\mathrm{A}}^{-} Q \\
& \frac{\partial Q}{\partial t}=+k_{\mathrm{A}}^{+} C A-k_{\mathrm{A}}^{-} Q
\end{aligned}
$$

At the crayfish neuromuscular junction, the AZs of presynaptic regions are mainly on axonal varicosities. The reaction-diffusion takes place in a region of volume, $\Omega$, that we take as a box that is subdivided into $N_{\mathrm{x}} N_{\mathrm{y}} N_{\mathrm{z}}$ grid boxes that are cubes of size $\Delta x=$ $\Delta y=\Delta z=\Delta x y z$. This region is bounded by the presynaptic membrane $\partial_{1} \Omega$ through which $\mathrm{Ca}^{2+}$ enters via channels in an AZ, and the boundary condition is $\partial C / \partial z=0$ because there is no diffusion through the cell membrane. The remaining surface con- 


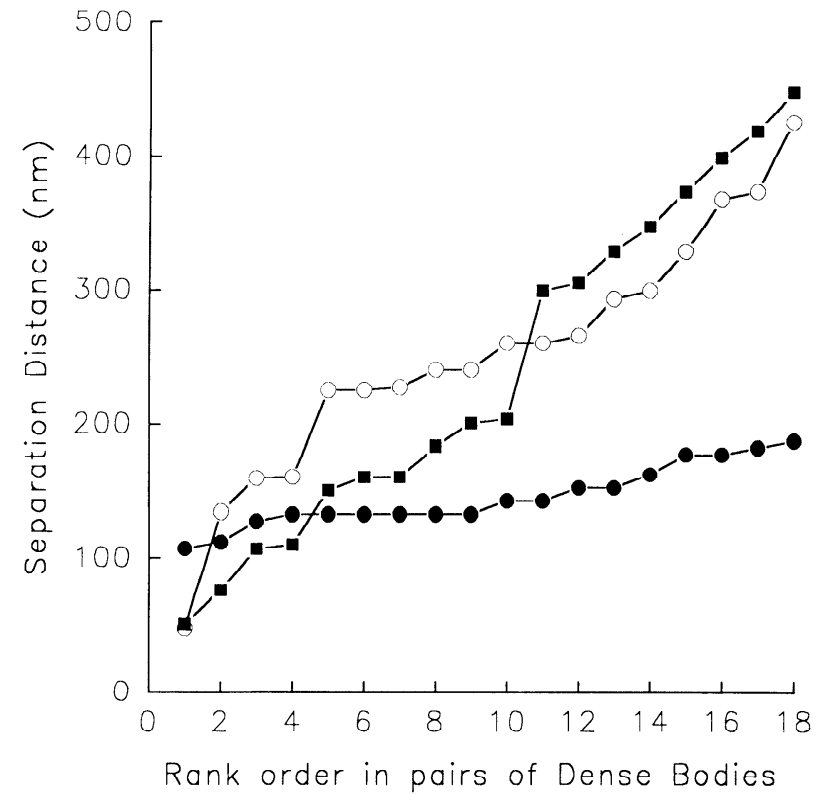

FIG. 3. Rank-ordered separation distances between pairs of AZs for 3 terminal varicosities of the crayfish opener muscle from which serial reconstructions and recordings of synaptic currents were obtained.

sists of the five walls that face axoplasm and are not a barrier to diffusion; thus the correct boundary condition is

$$
\underset{n \rightarrow \infty}{\operatorname{limit}} C=C_{0}
$$

where $n$ is an axis normal to (outward from) each of the five faces.

To accommodate the adjacent AZs, we used $N_{\mathrm{x}}=25, N_{\mathrm{y}}=13$, and $N_{\mathrm{z}}=18$ cubes. Also, there are long grid boxes (not shown in the figures) of length $8 \Delta x y z$ arranged in the direction normal to the five faces open to cytoplasm, which permit correct treatment of the boundary condition for diffusion through the open surface. This procedure gave a volume that is sufficiently large not to influence the reaction-diffusion results, but small enough to have practical computation times. Initial values for the concentrations are $C_{0}, A_{0}, Q_{0}(\mathrm{M})$, where $Q_{0}=\left(k_{\mathrm{A}}^{+} C_{0} A_{0}\right) / k_{\mathrm{A}}^{-}$, which is the steadystate solution of $E q$. 1, when given $C_{0}$ and $A_{0}$. A complete account of these procedures is given in Winslow et al. (1994b).

In the crayfish opener motor neuron, the $\mathrm{Ca}_{\mathrm{v}}$ channel resembles a P-type $\mathrm{Ca}_{v}$ channel with respect to current-voltage and pharmacological properties. The calcium current-voltage relation, in voltageclamped terminals, has onset activation, peak, and reversal potentials of $-35,-10$, and calcium equilibrium potential $\left(E_{\mathrm{Ca}}\right)=+30$ $\mathrm{mV}$, respectively (Wright et al. 1994). Funnel web spider toxin is the effective blocker in this preparation, as is the case for vertebrate P-type $\mathrm{Ca}_{\mathrm{v}}$ channels (Araque et al. 1994; Usowicz et al. 1992; Wright et al. 1994). The distinctive properties of the P-type channel were initially defined in cerebellar Purkinje cells. Here, the channels were shown to have single-channel maximum conductance, $g_{\mathrm{Ca}}^{\max }$, in the range of $9-19 \mathrm{pS}$ when $\mathrm{Ba}^{2+}$ replaced $\mathrm{Ca}^{2+}$ in patch-clamp measurements (Usowicz et al. 1992).

In general, current through a single channel is a product of single-channel maximum conductance; unit pulse (with times to open, stay open, and close); unit function for activation gating; unit function for inactivation gating; and net driving potential $\left[E(t)-E_{\mathrm{Ca}}\right]$. The membrane potential $E(t)$ is that of an action potential and $E_{\mathrm{Ca}}$ is the $\mathrm{Ca}^{2+}$ equilibrium potential, which takes into account the transmembrane $\mathrm{Ca}^{2+}$ gradient, $\left[\mathrm{Ca}^{2+}\right]_{\mathrm{i}}-$ extracellular $\mathrm{Ca}^{2+}$ concentration, and electrical gradient. These parameters are not known in detail for crayfish terminals, and it is beyond the scope of this investigation to use the individual channel gating properties and screening of the internal membrane surface charge to obtain the best estimate of net $\mathrm{AZ} \mathrm{Ca}^{2+}$ current flow. To characterize effects of $\mathrm{AZ}$ separation distances on net $\left[\mathrm{Ca}^{2+}\right]_{\mathrm{i}}$ response, we simplify matters by using a smooth square pulse to represent the calcium current rather than using the kinetics of a specific channel type. To bracket the magnitude of this current, we calculate the net $\mathrm{Ca}^{2+}$ driving potential, $E_{\mathrm{AP}}-E_{\mathrm{Ca}}$, at the peak of an action potential, $E_{\mathrm{AP}}=20 \mathrm{mV}$, and after repolarization of an action potential, $E_{0}-E_{\mathrm{Ca}}$, at the resting potential $E_{0}=-70 \mathrm{mV}$, when the $\mathrm{Ca}^{2+}$ current approaches the minimum and maximum values, respectively. For $E_{\mathrm{Ca}}=+30 \mathrm{mV}$, the corresponding two values of $E-E_{\mathrm{Ca}}$ are -10 and $-100 \mathrm{mV}$, respectively. The latter value is likely closer to the actual situation if most calcium enters the tcrminal as a "tail current" during repolarization of the action potential (Blundon et al. 1995; Llinas et al. 1976). Because the P-type $\mathrm{Ca}_{\mathrm{V}}$ channels have a conductance range of 9-19 pS for $\mathrm{Ba}^{2+}$, and it is known that $\mathrm{Ca}_{\mathrm{V}}$ channels are more permeable to $\mathrm{Ba}^{2+}$ than $\mathrm{Ca}^{2+}$, we chose a single $\mathrm{Ca}_{V}$ channel conductance of $g_{\mathrm{Ca}}^{\max }=14 \mathrm{pS}$. The duration of the channel current is taken as 1 $\mathrm{ms}$, which is a midrange of single-channel open times (Usowicz et al. 1992). This approach eliminates the complexity of channel dynamics and gives a readily interpretable response when only AZ separation distance is varied.

In summary, a calcium channel current is modeled as

$$
I_{\mathrm{Ca}}=g_{\mathrm{Ca}}^{\max }\left(E-E_{\mathrm{Ca}}\right) P\left(t, T_{\text {on }}, T_{\text {rise }}, T_{\mathrm{dur}}, T_{\text {fall }}\right)
$$

where $P$ is a unit pulse function, for which $T_{\text {un }}, T_{\text {rise }}, T_{\text {dur }}$, and $T_{\text {fall }}$ are on, rise, duration, and fall times. We used $T_{\text {dur }}=1.0 \mathrm{~ms}$, with $T_{\text {rise }}=T_{\text {fall }}=0.1 \mathrm{~ms}$. To avoid discontinuities in $\mathrm{Ca}^{2+}$ current $\left(I_{\mathrm{Ca}}\right)$ and thus shocks to the numerical integration, we used a pulse function with continuous first derivative (Winslow 1990).

In squid giant synapse it has been estimated that only $10 \%$ of the $\mathrm{Ca}_{\mathrm{V}}$ channels are open during an action potential (Pumplin et al. 1981). To bracket the response in the computations during the excitation pulse, we open either all or only $10 \%$ of the $\mathrm{Ca}_{\mathrm{V}}$ channels.

The rectangular grid of $N_{\mathrm{x}} \times N_{\mathrm{y}}$ of squares for the channel locations is the footprint of the mesh of $N_{\mathrm{x}} \times N_{\mathrm{y}} \times N_{\mathrm{z}}$ cubes used to discretize $\Omega$. In a cube containing a calcium channel, there are $-I_{\mathrm{Ca}}$ (A) of $\mathrm{Ca}^{2+}$ arriving (positive outward) in a volume of $(\Delta x y z)^{3} \mathrm{~cm}^{3}$; thus $E q .1 A$ for rate of change of calcium concentration becomes

$$
\frac{\partial C}{\partial t}=-k_{\mathrm{A}}^{+} C A+k_{\mathrm{A}}^{-} Q+D_{\mathrm{Ca}}\left(\frac{\partial^{2} C}{\partial x^{2}}+\frac{\partial^{2} C}{\partial y^{2}}+\frac{\partial^{2} C}{\partial z^{2}}\right)-\alpha I_{\mathrm{Ca}}
$$

$\left(1 A^{\prime}\right)$

where $I_{\mathrm{Ca}}$ is given by $E q .2$ and $\alpha$ converts $I_{\mathrm{Ca}}$ (A) to $\mathrm{M} / \mathrm{ms}$.

In the representative $\mathrm{AZ}$, which we used here, there are 13 $\mathrm{Ca}_{\mathrm{V}}$ channels remaining after one-third of the intramembraneous particles are removed for the $\mathrm{K}_{\mathrm{Ca}}$ channels as shown in Fig. 5. On the basis of the experiments of Roberts (1993), who evaluated intracellular nondiffusible buffers, and the calculations of Winslow et al. (1994b), we used a high-affinity immobile buffer with concentration $A-1.6 \mathrm{mM}$, with rate constants $k_{\mathrm{A}}^{+}=2 \times 10^{5} \mathrm{M}^{-1}$ $\mathrm{ms}^{-1}$ and $k_{\mathrm{A}}^{-}=50.0 \times 10^{-3} \mathrm{~ms}^{-1}$, which gives $K_{\mathrm{D}}=250 \mathrm{nM}$. On the basis of the analyses in Winslow et al. (1994b) and Winslow (1995), we calculated $\left[\mathrm{Ca}^{2+}\right]_{\mathrm{i}}$ in cytoplasm by using its diffusion coefficient in $\mathrm{I}_{2} \mathrm{O}, D_{\mathrm{Ca}}=7.92 \times 10^{-6} \mathrm{~cm}^{2} / \mathrm{s}$ in the presence of immobile buffer; this gives an apparent diffusion coefficient close to the value measured by Hodgkin and Keynes (1957). The set of partial differential equations for $\mathrm{Ca}^{2+}$, buffer, and product must be solved simultaneously. The system is far from equilibrium because $\partial C / \partial t, \partial A / \partial t$, and $\partial Q / \partial t$ vary by as much as $10^{4} \mathrm{M} / \mathrm{ms}$ in this type of simulation.

The inputs to the model are the time-dependent calcium channel 

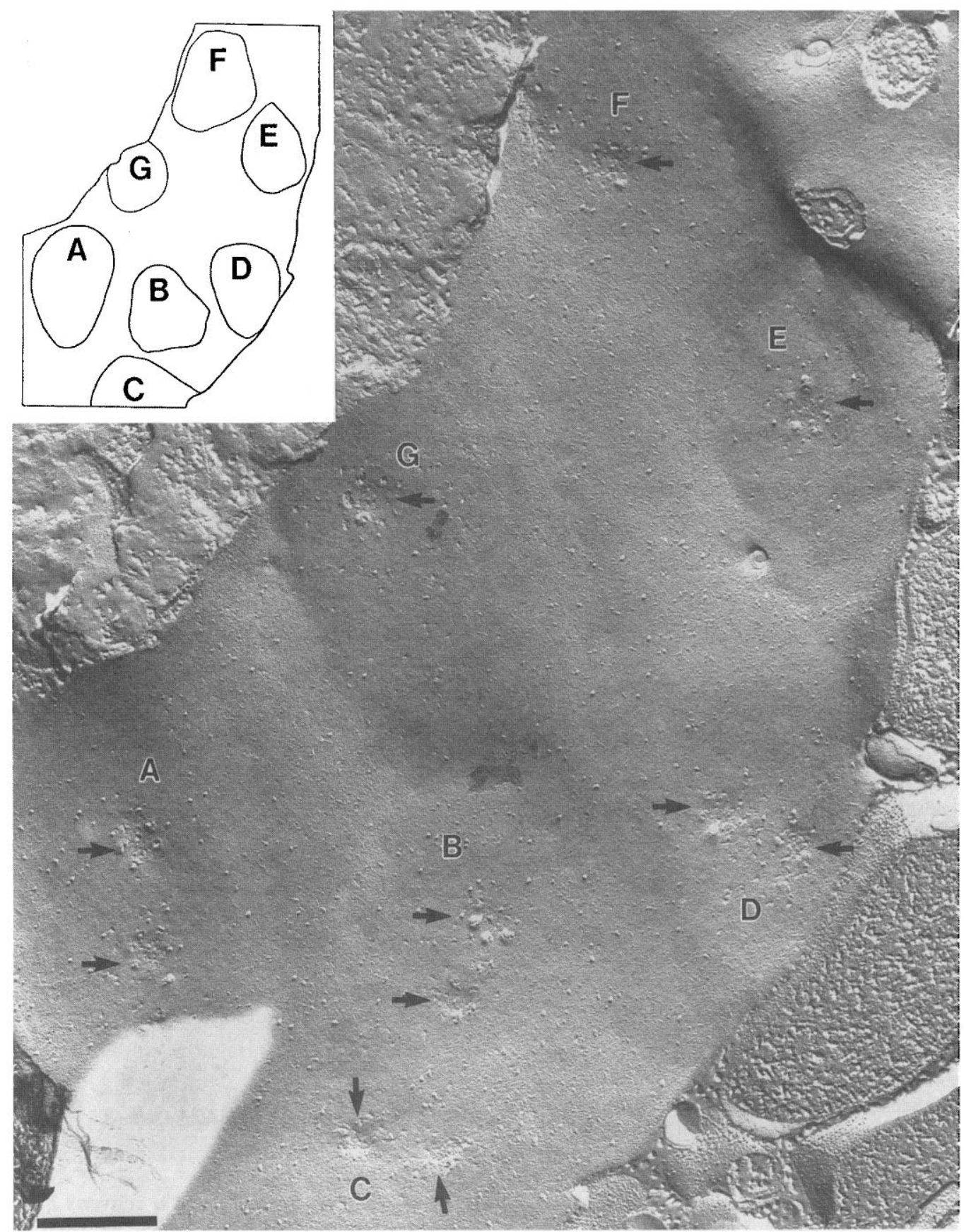

FIG. 4. Freeze-fracture view of $\mathrm{E}$ face of an excitatory nerve terminal to the crayfish opener muscle showing 7 synapses as large shallow depressions, each with 1 or $2 \mathrm{AZs}(\rightarrow)$ recognized by small volcano-like protrusions representing vesicle exocytosis. Inset outlines this region of the terminal with synaptic plateaus at a reduced scale. Four synapses (labeled AD) in the bottom of the picture each have $2 \mathrm{AZs}$, whereas the other 3 synapses (labeled E-G) in the top of the picture each have a single AZ. The distances between the AZ centers in each of the lower 4 synapses are: A, $348 \mathrm{~nm} ; \mathrm{B}, 344 \mathrm{~nm}$; , $226 \mathrm{~nm} ; \mathrm{D}, 235 \mathrm{~nm}$. Scale bar: $0.348 \mu \mathrm{m}$.

currents, which are the same for each channel location, and initial conditions $C_{0}, A_{0}$, and $Q_{0}$, with the latter determined from the steady state. Calcium arrives via the channels in the presynaptic AZs, diffuses, and combines with buffer according to Eqs. IA', $I B$, and $I C$ in the grid boxes containing a calcium channel. At all other grid boxes Eqs. $1 A-1 C$ apply. The outputs of the model are the values for the concentrations versus time. The spatial discretization of the partial differential equations results in a system of $3 N_{\mathrm{x}} N_{\mathrm{y}} N_{\mathrm{z}}$ nonlinear differential equations that are numerically integrated with the use of a numerical integration subroutine LSODES
(Hindmarsh 1980) on a Silicon Graphics Indigio computer. Further details are available in Winslow et al. (1994b).

\section{RESULTS}

\section{Distances between adjacent AZs}

The distances between pairs of AZs were measured for 95 synapses with multiple AZs uncovered in serial thin sectioning of three separate nerve terminal varicosities (Cooper 

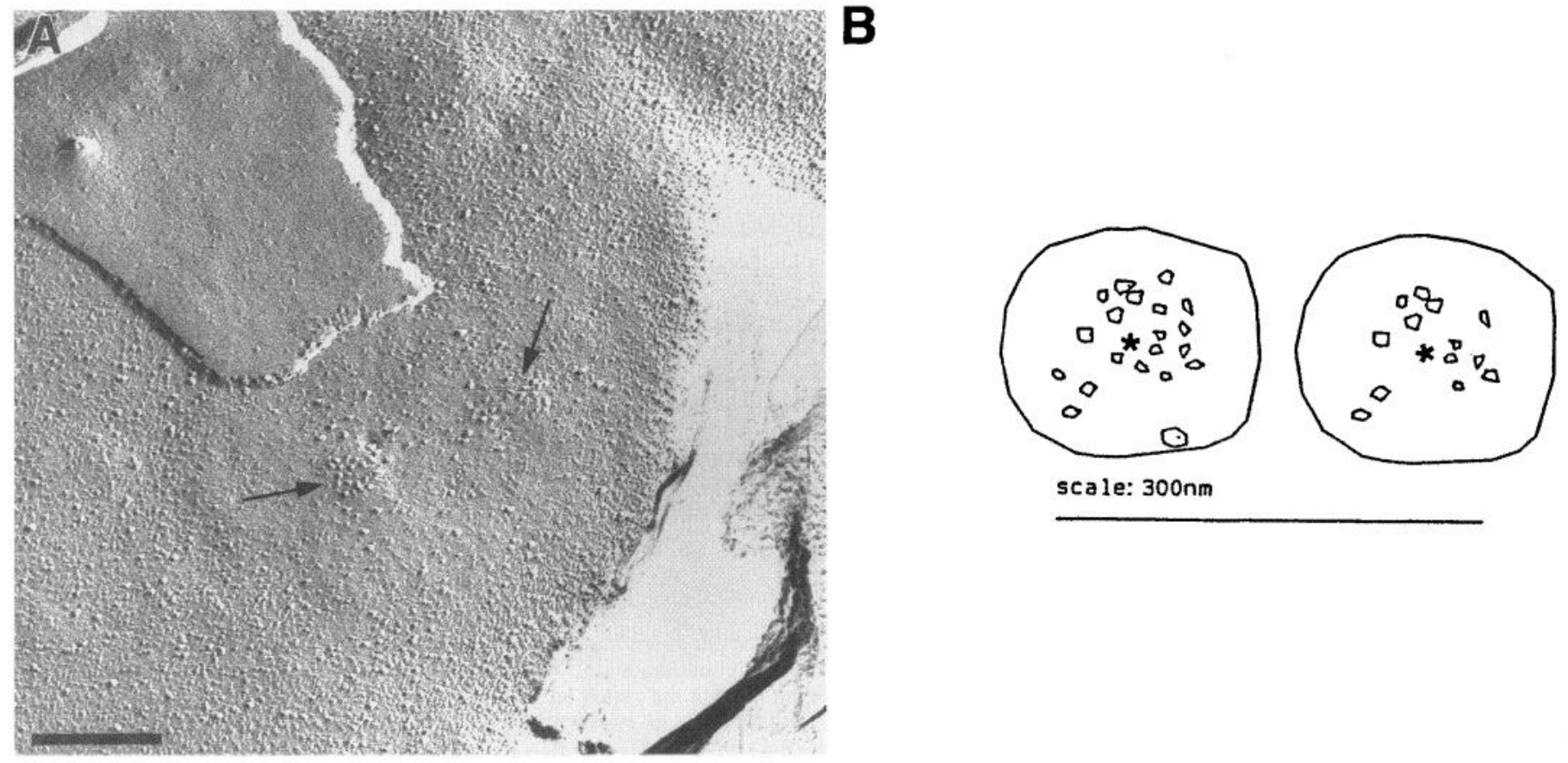

FIG. 5. A: freeze-fracture view of $\mathrm{P}$ face of an excitatory nerve terminal to the crayfish opener muscle showing a synapse as a slight plateau with 2 well-defined AZs represented by clusters of large intramembranous particles. The left AZ has a small depression on the periphery representing an exocytotic vesicle. Scale bar: $202 \mathrm{~nm}$. B: outline of an AZ has been traced from the video digitized image (left AZ of the pair shown in A). B, left: each of the putative channels has been outlined, and the centroid of the $\mathrm{AZ}$ is marked by the asterisk. $B$, right: $1 / 3$ of the traced channels have been randomly removed, leaving a representative distribution of voltage-activated calcium $\left(\mathrm{Ca}_{\mathrm{v}}\right)$ channels in an $\mathrm{AZ}$. A 20-nm grid mesh is superimposed on the representative AZ to determine the grid indexes of each channel. Here 1 copy of the AZ is shifted to the left by 100 $\mathrm{nm}$ and another copy is shifted to the right by $100 \mathrm{~nm}$ to give $200 \mathrm{~nm}$ of separation from centroid to centroid. The origin is at the midpoint between the $2 \mathrm{AZs}$. See also Figs. 8 and 10. Scale bar: $300 \mathrm{~nm}$.

et al. 1995a). Within a synapse, AZs are as close together as $60 \mathrm{~nm}$ (Fig. 3). The total range of separation distances is similar for each of the three varicosities. For varicosities $V_{1}, V_{2}$, and $V_{3}$ in Fig. 3, the number of dense bodies per varicosity for the indicated separation distances are, respectively: $\leq 100 \mathrm{~nm}: 2,1,0$; $\leq 150 \mathrm{~nm}: 7,4,13$; and $\leq 200$ $\mathrm{nm}: 9,4,18$. The results illustrate that among the more complex synapses, a wide range of $\mathrm{AZ}$ separations occurs, with relatively few $\leq 100 \mathrm{~nm}$.

\section{Response of $\mathrm{Ca}^{2+}$ at a single $\mathrm{AZ}$}

The initial computational experiments consisted of calculating $\left[\mathrm{Ca}^{2+}\right]_{i}$ as a function of space and time at a single AZ. As shown in Fig. 6, we first calculated $\left[\mathrm{Ca}^{2+}\right]_{\mathrm{i}}$ responses for a single $\mathrm{Ca}_{\mathrm{v}}$ channel $(10 \%$ of the 13 channels present in an AZ) at one channel condition $\left(E-E_{\mathrm{Ca}}=-10 \mathrm{mV}\right.$, which is at the peak of the test pulse) without buffer (Fig. $6 A$ ), and then with addition of immobile buffer (Fig. $6 B$ ). As an aid to reading the concentration versus time plots for each grid box, the grid box number is plotted at right at an ordinate value corresponding to the maximum $\left(\left[\mathrm{Ca}^{2+}\right]_{\mathrm{i}}\right.$ and [Immobile Product $]_{i}$ ) or the minimum of [Immobile Buffer $]_{i}$. This scheme holds for the subsequent time plots as well. Thus, for a single pulse and one channel, addition of $1.6 \mathrm{mM}$ immobile buffer lowers the overall maximum of $\left[\mathrm{Ca}^{2+}\right]_{\mathrm{i}}$ from 11.2 to $10.6 \mu \mathrm{M}$, and correspondingly for each of the indicated grid boxes.

Next, as shown in Fig. 7, $\left[\mathrm{Ca}^{2+}\right]_{\mathrm{i}}$ responses for the differ- ent channel conditions, without buffers, and with five test pulses, were calculated. In all experiments, five calcium current pulses at $100 \mathrm{~Hz}$ were used to correspond to the stimuli used to test short-term homosynaptic facilitation (Winslow et al. 1994b). In Fig. 7, the temporal responses for four channel conditions are shown. These conditions were selected to illustrate the range of effects possible in the model. The first two channel conditions utilize the driving force for calcium entry $\left(E-E_{\mathrm{Ca}}\right)$ that would occur at the peak of an action potential $\left(E_{\mathrm{AP}}\right)$, and the second two utilize the driving force after the action potential has repolarized to the initial membrane potential $\left(E_{0}\right)$. In each case, calculations are made with all channels open, and with only one channel open, as indicated in the legend of Fig. 7.

With no immobile buffer, $\left[\mathrm{Ca}^{2+}\right]_{\mathrm{i}}$ versus time is identical for each of the five pulses. Maximum $\left[\mathrm{Ca}^{2+}\right]_{\mathrm{i}}\left(C_{\max }\right)$ drops rapidly to $0.1 \mu \mathrm{M}$, the initial value, within $0.2 \mathrm{~ms}$ after each $I_{\mathrm{Ca}}$ pulse ceases, leaving no residual $\mathrm{Ca}^{2+}$ to add to the $\mathrm{Ca}^{2+}$ introduced by the next pulse. As shown in Fig. 7 , the $\left[\mathrm{Ca}^{2+}\right]_{\mathrm{i}}$ closely follows the entering $\mathrm{Ca}^{2+}$ current, $I_{\mathrm{Ca}}$, which is the same for each channel. For the four cases the overall maximum, $C_{\max }$, within $20 \mathrm{~nm}$ of the presynaptic membrane is, respectively: $11.0,42.0,113.0$, and $420.0 \mu \mathrm{M}$. The major response differences associated with the four channel conditions are the spatial spread of the response and the scaling of the response. The $\left[\mathrm{Ca}^{2+}\right]_{\mathrm{i}}$ response for 13 channels is more spread out than for one channel (compare $B$ and $D$ with $A$ and $C$, and also the corresponding graphs in Fig. 9).

The effects of adding immobile buffer to the system while 


$$
\left[C a^{2+}\right]_{i}(\mu M)
$$
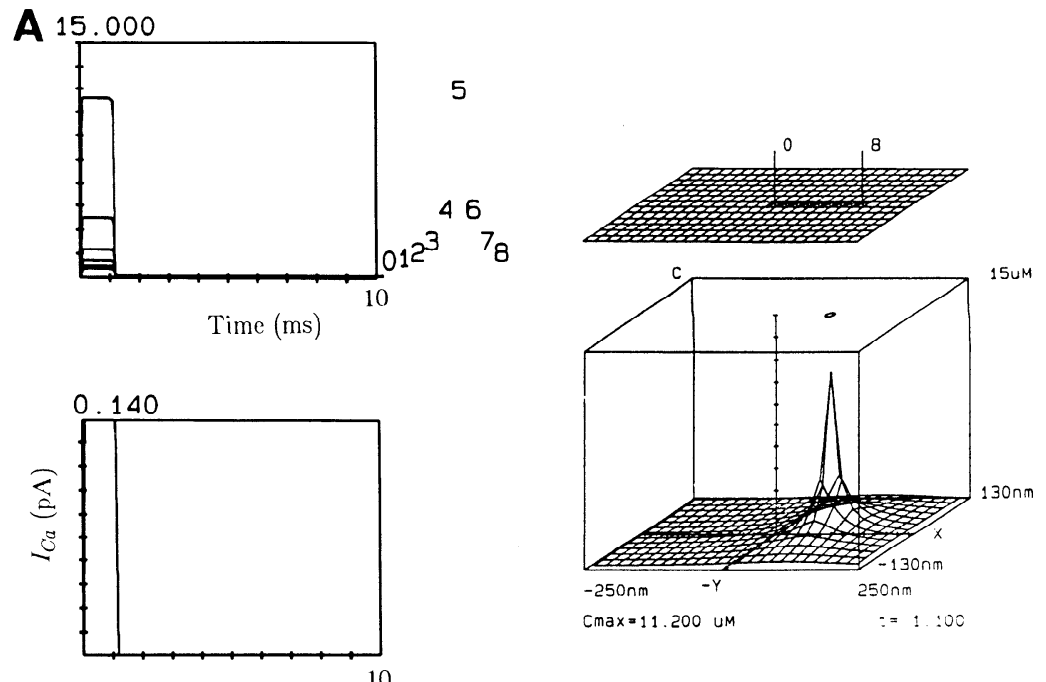

10

$$
\left[\mathrm{Ca}^{2+}\right]_{i}(\mu \mathrm{M})
$$

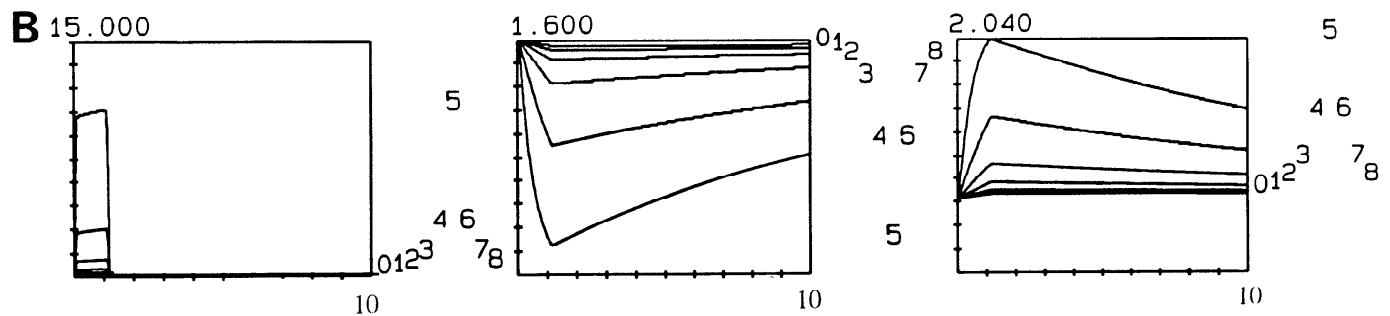

10
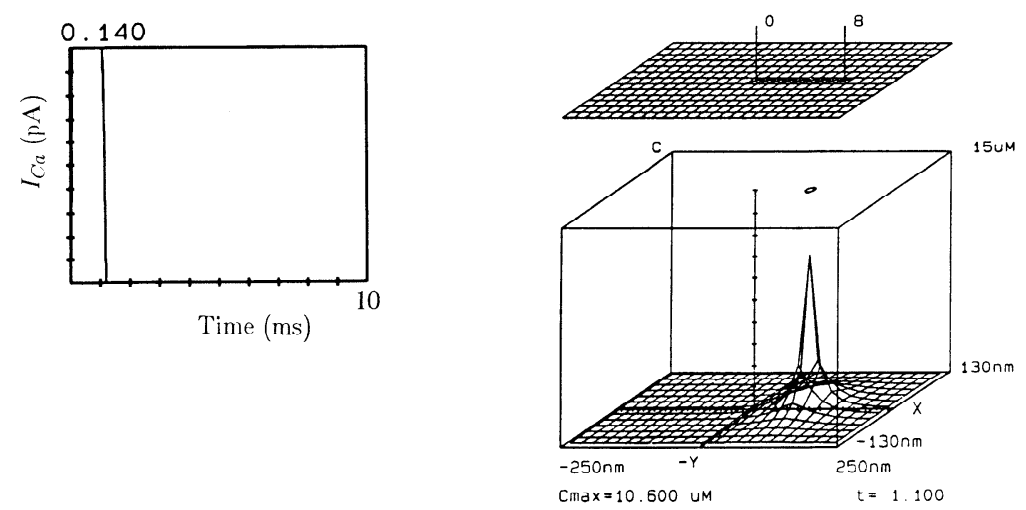

FIG. 6. Effects of $\mathrm{Ca}^{2+}$ buffer on intracellular $\mathrm{Ca}^{2+}$ concentration $\left(\left[\mathrm{Ca}^{2+}\right]_{\mathrm{i}}\right)$ in response to 1 smooth square-wave pulse activating a single $\mathrm{Ca}^{2+}$ channel. This channel has a driving gradient of $E$ - calcium equilibrium potential $\left(E_{\mathrm{Ca}}\right)=$ peak of an action potential $\left(E_{\mathrm{AP}}\right)-E_{\mathrm{Ca}}=-10 \mathrm{mV}$ and conductance $g_{\mathrm{Ca}}=14 \mathrm{pS}$. The pulse is $1 \mathrm{~ms}$ in duration and has $0.1 \mathrm{~ms}$ rise and fall times. $A$ : without $\mathrm{Ca}^{2+}$ buffer. $B$ : with immobile $\mathrm{Ca}^{2+}$ buffer. The 3-dimensional plots in $A$ and $B$ are of $\left[\mathrm{Ca}^{2+}\right]_{\mathrm{i}}$ vs. $X$ and $Y$ within $20 \mathrm{~nm}$ of the presynaptic membrane. The grid boxes, numbered $0-8$, are shown on the grid superior to the 3-dimensional plot. The maximum of $\left[\mathrm{Ca}^{2+}\right]_{\mathrm{i}}$, and $[\text { Immobile Product }]_{\mathrm{i}}$ response in each grid box plotted vs. time, directly correspond to the vertical positions of the grid box number given on the right of the 2-dimensional plots. For [Immobile Buffer $]_{\mathrm{i}}$ the vertical position of the grid box numbers on the right correspond to the minimum over time, per grid box. $C_{\max }$, maximum $\left[\mathrm{Ca}^{2+}\right]_{\mathrm{i}}(\mu \mathrm{M})$; t, time (ms).

maintaining the same initial entry of $\mathrm{Ca}^{2+}$ are illustrated by the computation of Fig. 8. When immobile buffer $\left(A_{0}=1.6\right.$ $\mathrm{mM}$ ) is present, two things happen to the temporal response. First, the overall maximum, $C_{\max }$, decreases slightly to 10.7 , $39.5,111.0$, and $418.0 \mu \mathrm{M}$, for $A-D$, respectively. Corresponding percent reductions from the computations of Fig. 7 are $2.73,5.95,1.77$, and $0.48 \%$, respectively. This reflects the spatial and temporal effects of loading and unloading the immobile buffer, as illustrated in the graphs of available buffer, A, versus time (Fig. 8, middle column). Second, there is released residual $\mathrm{Ca}^{2+}$ from immobile product after cessation of each incoming $\mathrm{Ca}^{2+}$ current pulse. For the four conditions, $A-D$, the overall maximum of residual $\left[\mathrm{Ca}^{2+}\right]_{\mathrm{i}}$, at $t=50 \mathrm{~ms}$, which would be present at the start of a sixth 

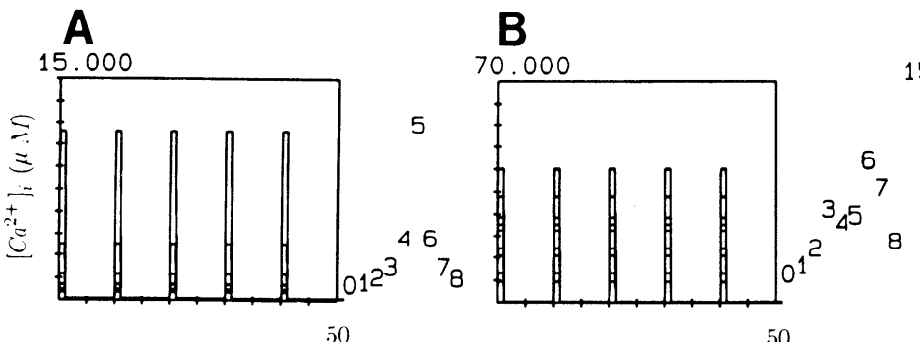

50

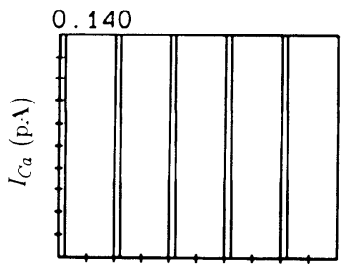

50

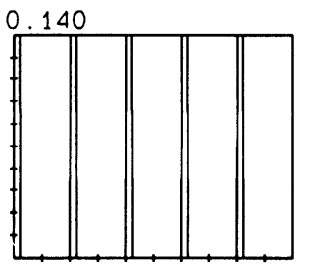

50

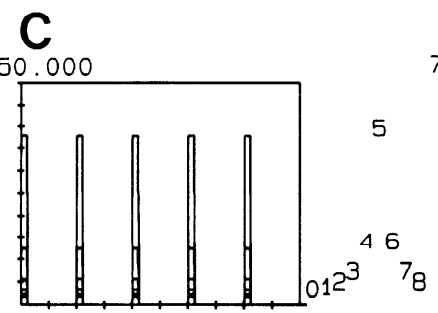

50

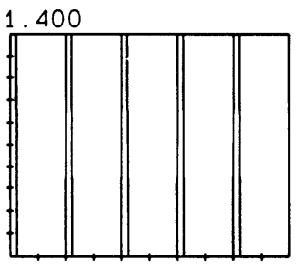

50
D

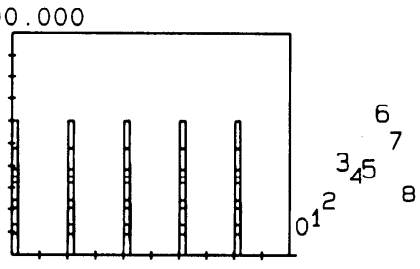

50

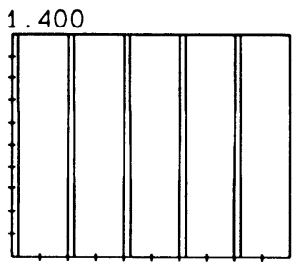

50

FIG. 7. Calculated responses of $\left[\mathrm{Ca}^{2+}\right]_{i}$ as a function of time in the presence of no $\mathrm{Ca}^{2+}$ buffers. The effects of 4 different channel conditions on the temporal response of $\left[\mathrm{Ca}^{2+}\right]_{i}$ at 1 isolated $\mathrm{AZ}$ are shown when the $\mathrm{Ca}_{\mathrm{V}}$ channels are opened by 5 smooth square-wave pulses delivered at $100 \mathrm{~Hz}$. The pulses are $1 \mathrm{~ms}$ in duration and have $0.1 \mathrm{~ms}$ rise and fall times. The single $\mathrm{Ca}^{2+}$ channel conductance is $g_{\mathrm{Ca}}=14 \mathrm{pS}$. The results for the 4 channel conditions are rank-ordered by amplitude of maximum response. $A: E-E_{\mathrm{Ca}}-E_{\mathrm{AP}}-E_{\mathrm{Ca}}=-10 \mathrm{mV}$ and $10 \%$ of $13 \mathrm{Ca}_{\mathrm{v}}$ channels (1) opening. $B: E-E_{\mathrm{Ca}}=E_{\mathrm{AP}}-$ $E_{\mathrm{Ca}}=-10 \mathrm{mV}$ and all $13 \mathrm{Ca}_{\mathrm{v}}$ channels in AZ opening. $C: E-E_{\mathrm{Ca}}=E_{0}-E_{\mathrm{Ca}}=-100 \mathrm{mV}$ and $10 \%$ of $13 \mathrm{Ca}$ channels (1) opening. $D: E-E_{\mathrm{Ca}}=E_{\mathrm{O}}-E_{\mathrm{Ca}}=-100 \mathrm{mV}$ and all $13 \mathrm{Ca}_{\mathrm{v}}$ channels in AZ opening. Bottom: $\mathrm{Ca}^{2+}$ current, $I_{\mathrm{Ca}}$, per individual channel. Because of the different $E-E_{\mathrm{Ca}}$ values, $I_{\mathrm{Ca}}$ is different for conditions $A$ and $B$, where $\max \left(I_{\mathrm{Ca}}\right)=0.14$ pA, compared with $C$ and $D$, where $\max \left(I_{\mathrm{Ca}}\right)=1.40 \mathrm{pA}$. The diffusion coefficient of $\mathrm{Ca}^{2+}$ is as in $\mathrm{H}_{2} \mathrm{O}, D_{\mathrm{Ca}}=7.92 \times$ $10^{-6} \mathrm{~cm}^{2} / \mathrm{s}$. Top: $\left[\mathrm{Ca}^{2+}\right]_{\mathrm{i}}$ vs. time $(t)$ at centers of grid box locations, $0-8$, along the $X$-axis. (The grid box locations are shown in Fig. 9, top $)$. For the case of 1 channel $(A$ and $C)$ that is in grid box 5 , the maximum of $\left|\mathrm{Ca}^{2+}\right|_{i}$ occurs in that grid box. For the case of 13 channels $(B$ and $D)$ the maximum occurs in grid box 6 . The numbers at the right side of each graph refer to the grid box locations, and are positioned vertically to indicate the maximum amplitude of $\left[\mathrm{Ca}^{2+}\right]_{\mathrm{i}}$ over time, per grid box, as in Fig. 6. Scales-Horizontal: $50 \mathrm{~ms}$. Vertical: bottom of $A$ and $B, 0.140 \mathrm{pA}$; bottom of $C$ and $D, 1.40 \mathrm{pA}$; top of $A-D, 15,70,150$, and $700 \mu \mathrm{M}$, respectively.

pulse, is $0.16,0.44,0.57$, and $0.77 \mu \mathrm{M}$, respectively. These values represent a $50-700 \%$ increase above the resting value, $C_{0}=0.1 \mu \mathrm{M}$. This released residual $\left[\mathrm{Ca}^{2+}\right]_{\mathrm{i}}$ is also seen in the graphs of the concentration of product $Q$ versus time (Fig. 8, right column). The maximum concentration of bound product is $2.12,2.23,2.40$, and $2.24 \mathrm{mM}$ for the rank-ordered conditions $A-D$. The initial concentration of immobile buffer is such that it is repetitively bound and unbound with each pulse of $\mathrm{Ca}^{2+}$, increasing from unsaturated to saturated for the four rank-ordered conditions. The concentration of the product is enhanced with repeated pulses.

For the four conditions, $A-D$, in which the calcium cloud expands, there is an increased spread of immobile buffer saturation. This is seen in Fig. 8, middle column, showing $[A]_{\mathrm{i}}$ versus time with the numbers indicating the minimum value per plot. Similarly, the product (right column) shows the spread of the maximum concentration values. The response for condition $D$, in which 13 channels are open at $E-E_{\mathrm{Ca}}=-100 \mathrm{mV}$, shows complete saturation of immobile buffer per channel current pulse.

Linearity of $\left[\mathrm{Ca}^{2+}\right]_{i}$ with respect to $I_{C a}$, but not to number of channels and buffer

When the driving force for $\mathrm{Ca}^{2+}$ entry is increased 10fold and no buffer is present, the computation shows a corresponding 10 -fold increase in $\left[\mathrm{Ca}^{2+}\right]_{i}$, both for the case of
$1 \mathrm{Ca}_{\mathrm{V}}$ channel (Fig. 7, $A$ and $C$ ) and for the case of 13 $\mathrm{Ca}_{\mathrm{V}}$ channels (Fig. 7, $B$ and $D$ ). This demonstrates the linearity of the system's response to increased $I_{\mathrm{Ca}}$ with no buffers.

When the number of active $\mathrm{Ca}_{\mathrm{V}}$ channels is increased from 1 to 13 , the maximum response of $\left[\mathrm{Ca}^{2+}\right]_{\mathrm{i}}$ is not increased 13-fold (Fig. 7: compare $A$ and $C$ with $B$ and $D$, respectively). This demonstrates that $C_{\max }$ does not increase linearly with the number of channels in an AZ, because of the spatial dispersion of the channels.

When buffer is added, the system $(E q .1)$ is clearly nonlinear because $\partial C / \partial t, \partial A / \partial t$, and $\partial Q / \partial t$ have the term $k_{\mathrm{A}}^{+} C B$, which is a product of $C=\left[\mathrm{Ca}^{2+}\right]_{\mathrm{i}}$ and buffer, $B$. Thus presence of buffer and multiple spatially dispersed channels are two sources of nonlinear behavior.

\section{Spatial distribution of $\mathrm{Ca}^{2+}$}

The spatial concentrations of $\mathrm{Ca}^{21}$ around one isolated $\mathrm{AZ}$ for the channel conditions with and without immobile buffer are shown in Fig. 9. The $\left[\mathrm{Ca}^{2+}\right]_{\mathrm{i}}$ versus $X-Y$ plot is shown for the time when the response is maximal $(t=41.1$ $\mathrm{ms}$ ) at the end of the fifth pulse of input current $I_{\mathrm{Ca}}$. The channel locations are shown projected on the superior surface of the spatial response graphs. The responses with immobile buffer, shown in Fig. 9, top row, are slightly scaleddown versions of those with no buffer (bottom row). Even within the $\mathrm{AZ}$, the response magnitude is highly dependent 
$\left[\mathrm{Ca}^{2+}\right]_{i}(\mu \mathrm{M}) \quad$ [Immobile Buffer $]_{i}(m M)$ [Immobile Product $]_{i}(\mathrm{~m} M)$
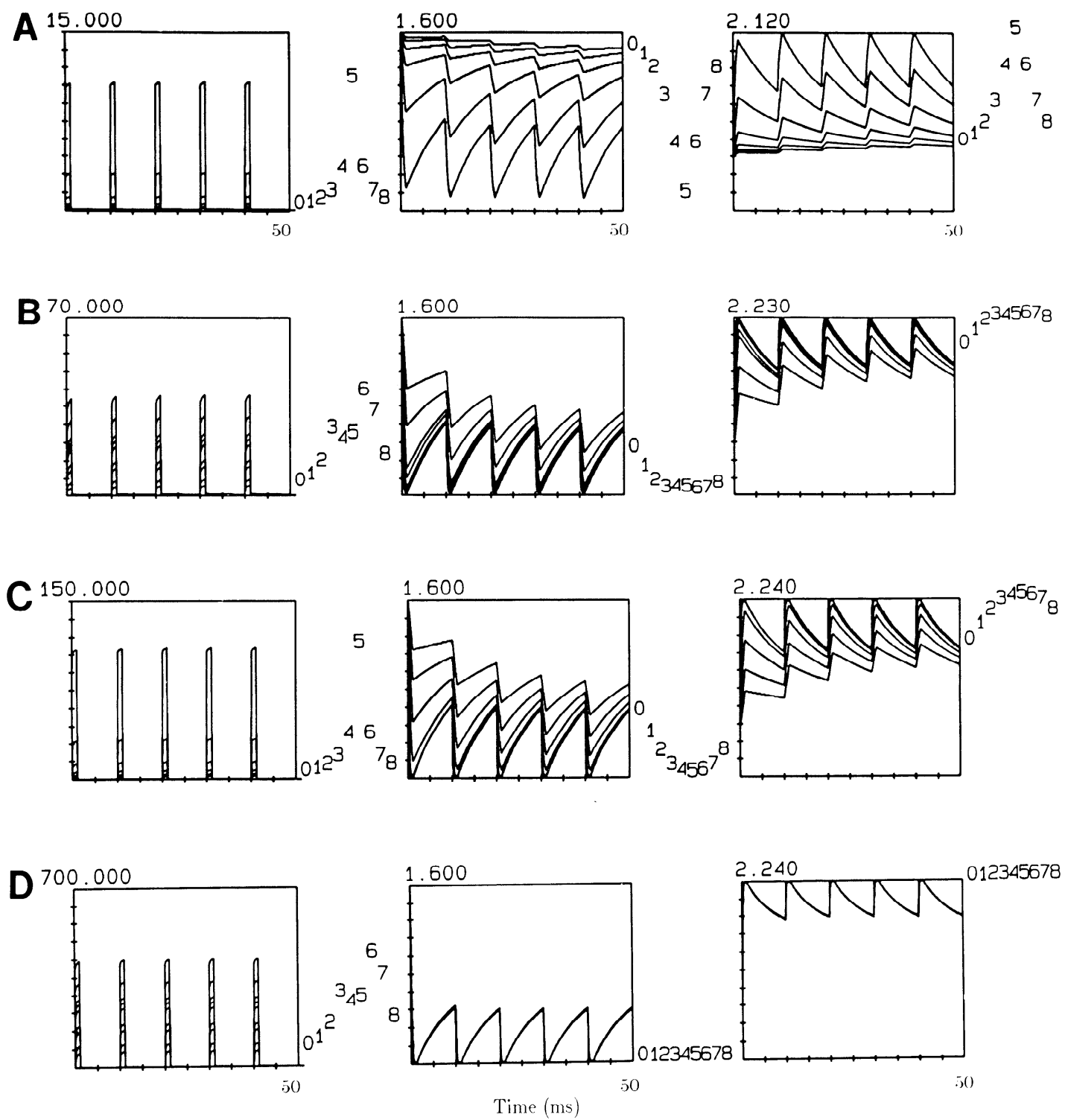

FIG. 8. Effects of immobile buffer on the time course of $\mathrm{Ca}^{2+}$ concentrations at $1 \mathrm{AZ}$, for different conditions. The 4 conditions $A-D$ are the same as in Fig. 7; but now $1.6 \mathrm{mM}$ of immobile buffer, with concentration [immobile Buffer] $]_{\mathrm{i}}$ has been added, which produces immobile product, with concentration [immobile Product $]_{\mathrm{i}}$. Left column: $\left[\mathrm{Ca}^{2+}\right]_{\mathrm{i}}$ vs. time. Middle column: [immobile buffer $]_{\mathrm{i}}\left([A]_{\mathrm{i}}\right)$ vs. time. Right column: [Immobile Product $]_{\mathrm{i}}\left([Q]_{\mathrm{i}}\right)$ vs. time. Numbers at the right side of each graph refer to the grid box locations, and are positioned to indicate the maximum $\left(\left[\mathrm{Ca}^{2+}\right]_{\mathrm{i}}\right), \operatorname{minimum}\left([A]_{\mathrm{i}}\right)$, and maximum $\left([Q]_{\mathrm{i}}\right)$, in each grid box. Note the inverse relationship between $\left[\mathrm{Ca}^{2+}\right]_{\mathrm{i}}$ and $[A]_{\mathrm{i}}$, but direct relationship between $\left[\mathrm{Ca}^{2+}\right]_{\mathrm{i}}$ and $[Q]_{\mathrm{i}}$. For all the conditions, the plots for $[A]_{\mathrm{i}}$ and $[Q]_{\mathrm{i}}$ have 8 response locations but those for the distal locations coincide. The buffer and product responses change from very spread out to all the same as the total amount of $\mathrm{Ca}^{2+}$ is increased in the sequence $A-D$.

on channel location and density. Because the grid boxes used for the time plots are along the $X$-axis and the overall maximums of the spatial plots can occur off the $X$-axis, where the density of channels is greater (Fig. 9, $B$ and $D$ ), the overall maximums do not agree with the maximums of the curves in Figs. $7, B$ and $D$, and $8, B$ and $D$, which are time plots of $\left[\mathrm{Ca}^{2+}\right]_{\mathrm{i}}$ within the grid boxes.

\section{Effect of separation distance between two AZs}

Two identical copies of the typical AZ were arranged with different separations between their centers, as shown in Fig.
11. We examined the case of all $13 \mathrm{Ca}_{\vee}$ channels opening and $E-E_{\mathrm{Ca}}=-100 \mathrm{mV}$, with buffer present. The temporal responses shown in Fig. 10, $A-D$, are for the separation distances of $300,200,100$, and $50 \mathrm{~nm}$, respectively. The control or $\infty$ separation is for one AZ shown in Fig. $8 D$. The $\left[\mathrm{Ca}^{2+}\right]_{\mathrm{i}}$ response is enhanced between and within the two AZs as the separation distance is decreased. The maximum of $\left[\mathrm{Ca}^{2+}\right]_{i}$ in the grid boxes $0-8$ is spread out for one AZ (also seen in the spatial responses of Fig. 9, top row) and increases to a maximum for $50 \mathrm{~nm}$ separation, in grid boxes $0,1,2$, i.e., at the center of the membrane response region, $\partial_{1} \Omega$. For the five decreasing separation distances, the 
A
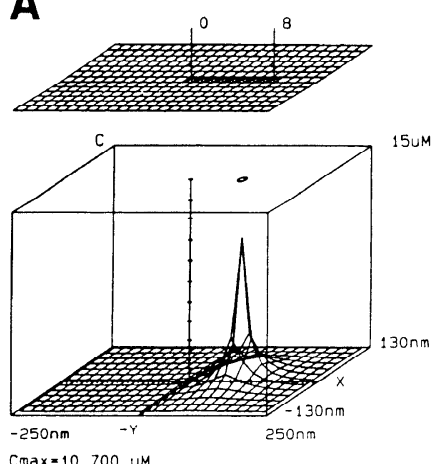

$C \max =10.700$ uM

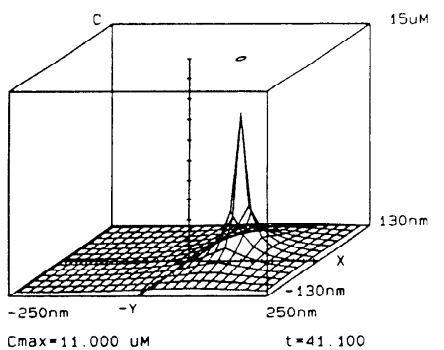

B

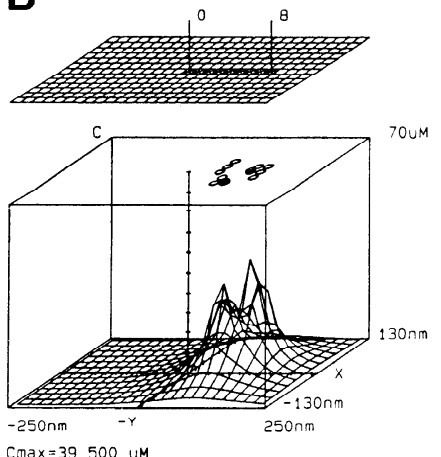

Cmax $=39.500 u M$

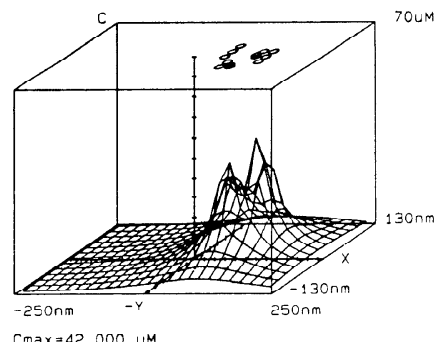

C
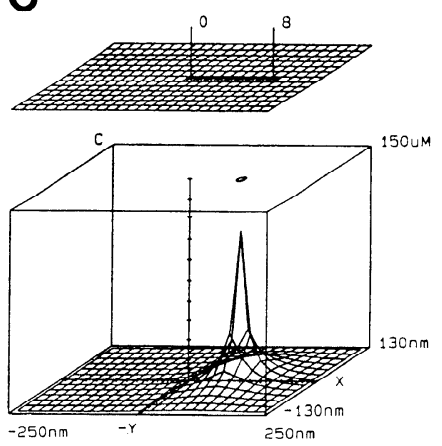

Cmax $=111.000$ uM

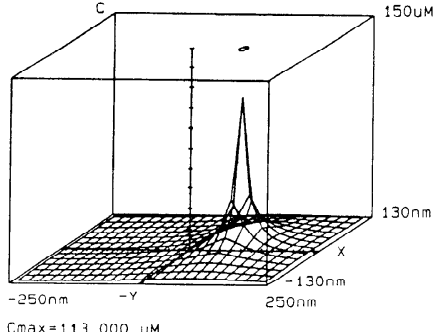

D
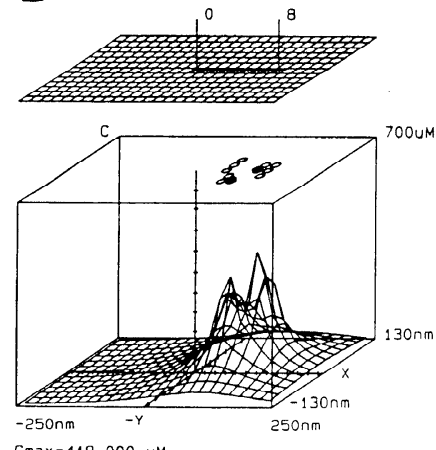

$\operatorname{Cmax}=418.000$ UM

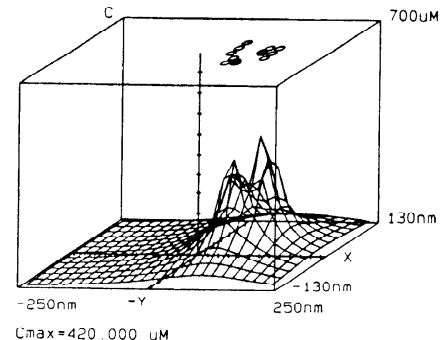

HIG. 9. Spatial distribution of $\left[\mathrm{Ca}^{2+}\right]_{\mathrm{i}}$ for 1 isolated $\mathrm{AZ}$ at the time of maximum response to the 5 th of the 5 smooth square-wave pulses shown for different channel conditions, with and without immobile buffer. The 4 conditions, $A-D$, are the same as in Figs. 7 and 8. $C_{\max }$, maximum $\left[\mathrm{Ca}^{2+}\right]_{\mathrm{i}}$ over $X, Y$, and time. The time $(t)$ at which $C_{\max }$ occurs is $41.1 \mathrm{~ms}$ for all of these plots. Top row: location of grid boxes $0-8$, whose responses are reported in Figs. 7 and 8 . Middle row: responses with immobile buffer. The channel locations are shown projected on the superior surface of the represented volume. Boltom row: responses with no immobile buffer. Scales $-X:(-250,+250 \mathrm{~nm})$ by $Y:(-130,+130 \mathrm{~nm})$. Vertical: 0 to 15 , 70,150 , and $700 \mu \mathrm{M}$.

overall maximum values of $\left[\mathrm{Ca}^{2+}\right]_{\mathrm{i}}$ in space and time, $C_{\max }$, are, respectivcly, 418, 430, 442, 498, and $696 \mu \mathrm{M}$. The responses at the midpoint between the two AZs (coordinate origin and plotting grid box location 0 ) become $62.8,63.2$, 134,365 , and $453 \mu \mathrm{M}$, respectively. Observe that the immobile buffer is saturated for each calcium current pulse regardless of the separation distance and the corresponding product peaks at the same time (Fig. $8 D$ ).

When the separation distance between AZ centers is varied, the two main indicators of $[\mathrm{Ca}]_{\mathrm{i}}$ response are the concentrations at the midpoint of the two AZs, plotting location 0, $C_{\text {mid }}$, and the overall maximum, $C_{\max }$ (see Fig. 11). These two measures are plotted against separation distance in Fig. 12 , for the four conditions. For comparison with the results in Winslow et al. (1994b), the condition of 13 channels opening, with driving force for $\mathrm{Ca}^{2+}$ entry of $125 \mathrm{mV}$, and $g_{\mathrm{Ca}}=1 \mathrm{pS}$ is included (*) and gives a low range value for calcium current and thus a low range response. Clearly, for paired AZs with a separation distance $\leq 200 \mathrm{~nm}$, there is a greater increase in $\left[\mathrm{Ca}^{2+}\right]_{\mathrm{i}}$ than for a single $\mathrm{AZ}$, particularly at the $\mathrm{AZ}$ perimeter where two AZs start to overlap.

\section{DIS CUSSION}

The question raised by earlier structural studies was whether structural complexity at a synapse, as evidenced by closely spaced AZs, could influcnce the probability of depolarization-evoked neurotransmission. The present study addresses this question by modeling the spatial distribution of $\mathrm{Ca}^{2+}$ entering through $\mathrm{Ca}_{\mathrm{V}}$ channels. In the crayfish motor neuron, a wide range of separation distances between pairs of AZs was observed. The modeling study indicates that localized $\mathrm{Ca}^{2+}$ domains of individual adjacent $\mathrm{AZs}$ can interact to create a higher local $\left[\mathrm{Ca}^{2+}\right]_{\mathrm{i}}$ in regions in and near the AZ. However, the relative importance of this interaction depends on the separation between the AZs and on how many individual calcium channels are opened by depolarization.

For this study, the computational approach was needed because measurements cannot resolve $\left[\mathrm{Ca}^{2+}\right]_{i}$ within the $\mathrm{Ca}^{2+}$ domains. Our computed results are compatible with the results from aequorin averaged over longer times and distances in squid giant synapse (Llinas et al. 1992). In the latter study, the lower limit of resolution is $500 \mathrm{~nm}$, which is twice the diameter of the AZs found in our study. Thus imaging $\left[\mathrm{Ca}^{2+}\right]_{i}$ in individual AZs of small synapses remains problematic.

\section{Computational experiments}

The starting point for the computational work was the concept that $\mathrm{Ca}^{2+}$ entering through $\mathrm{Ca}_{\mathrm{V}}$ channels exists transiently in a localized spatial domain. The discrete $\mathrm{Ca}_{\mathrm{V}}$ channels within an $\mathrm{AZ}$ and the interaction of their $\mathrm{Ca}^{2+}$ microdomains have been the subject of several studies and reviews (Augustine and Neher 1992; Augustine et al. 1991; Fogelson and Zucker 1985; Parnas and Segel 1988; Simon and Llinas 1985; Smith et al. 1993; Zucker 1989; Zucker and Fogelson 1986). The present modeling work suggests that AZs can also generate $\mathrm{Ca}^{2+}$ macrodomains with many properties analogous to those of channel microdomains, in particular the overlapping of $\mathrm{Ca}^{2+}$ domains of neighboring AZs. 


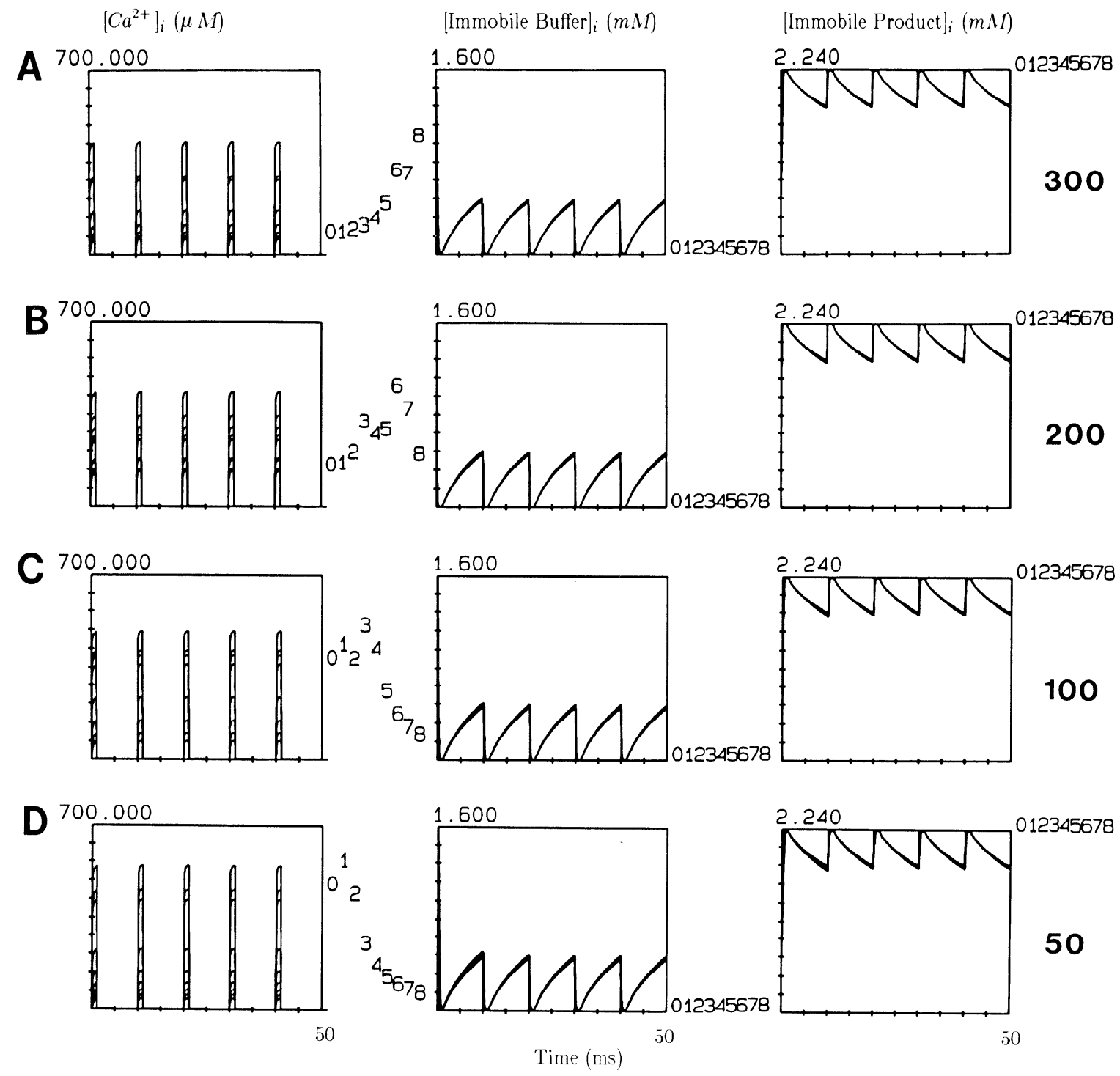

FIG. 10. Effects of separation distance between $2 \mathrm{AZs}$ on the temporal response of calcium, buffer, and immobile product concentration to 5 smooth square-wave pulses. The conditions are the same as in Figs. $8 D$ and $9 D$ : all $13 \mathrm{Ca}_{\mathrm{V}}$ channels open and $E-E_{\mathrm{Ca}}=-100 \mathrm{mV}$. $A-D$ : responses for $2 \mathrm{AZs},\left[\mathrm{Ca}^{2+}\right]_{\mathrm{i}},[\text { Immobile Buffer }]_{\mathrm{i}}=[A]_{\mathrm{i}},[\text { Immobile Product }]_{\mathrm{i}}=$ $[Q]_{\mathrm{i}}$ vs. $t$, with variable separation between centers of AZs: $300 \mathrm{~nm}(A), 200 \mathrm{~nm}(B), 100 \mathrm{~nm}(C)$, and $50 \mathrm{~nm}(D)$. The numbers to the right of each graph arc as in Fig. 8. Location of grid boxes 0-8 are fixed and the AZs have smaller separation distance as in Fig. 11. Note that grid box 0 is the midpoint between the two AZs. As a control (or infinite separation), compare with the response for $1 \mathrm{AZ}(\mathrm{Fig} .8 \mathrm{D})$. Although $\left[\mathrm{Ca}^{2+}\right]_{\mathrm{i}}$ varies among grid boxes, the immobile buffer saturates and unsaturates per pulse, which produces the inverse effect for the immobile product. Scales-Horizontal: $(0,50 \mathrm{~ms})$. Vertical: $(0,700 \mu \mathrm{M}),(0,1.6 \mathrm{mM})$, and $(0,2.24 \mathrm{mM})$.

The computational preparation uses a typical inferred distribution of $\mathrm{Ca}_{\mathrm{V}}$ channel locations within an $\mathrm{AZ}$, and varies the separation distances of AZs as observed in reconstructions. Recent reports have characterized the $\mathrm{Ca}_{\mathrm{V}}$ channels in crayfish motor nerve terminals (Wright et al. 1994) and muscle fibers (Araque et al. 1994) as P type. We used a $\mathrm{Ca}^{2+}$ current pulse with the driving force and conductance of a P-type channel but with generic duration, so that the $\left[\mathrm{Ca}^{2+}\right]_{\mathrm{i}}$ response at AZs is not complicated by the channel dynamics. Conditions of immobile $\mathrm{Ca}^{2+}$ buffer and no mobile $\mathrm{Ca}^{2+}$ buffer were used in a conservative approach to simulations of synaptic function. Roberts (1993) showed that in frog saccular hair cells, there is $1.6 \mathrm{mM}$ buffer that is a combination of mobile and immobile buffers. Because actual concentrations and rates for immobile and mobilc buffers in the cytoplasm of the crayfish terminal are unknown, we used the value estimated by Roberts (1993). When the actual values are known for crayfish terminals, similar results would be expected and can be scaled accordingly. We used only immobile buffer because it causes a slower apparent diffusion coefficient of $\mathrm{Ca}^{2+}$ (Winslow et al. 1994b). The apparent diffusion coefficient is caused by immobile buffers and possible tortuosity of $\mathrm{Ca}^{2+}$ movement through the cytoplasm. We did not evaluate the effects of tortuosity in the current model. Binding sites of $\mathrm{Ca}^{2+}$ on vesicles may also act as an immobile buffer; but, because the binding coefficients for vesicular associated proteins are not well understood, we did not include this in the present 

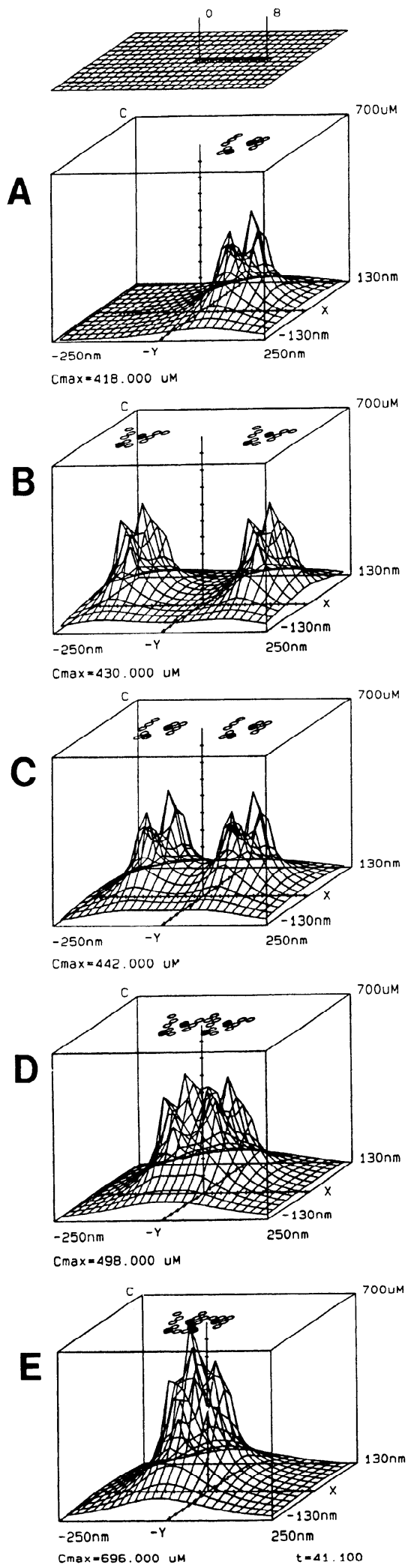

FIG. 11. Effects of separation distance between centers of 2 nearby AZs on the spatial distribution of $\left[\mathrm{Ca}^{2+}\right]_{i}$, under the same conditions as in Figs. $8 D$ and $9, A-D$. The spatial response is shown for the 5th of 5 smooth square-wave $I_{\mathrm{Ca}}$ pulses when $\left[\mathrm{Ca}^{2+}\right]_{\mathrm{i}}$ is maximum, $C_{\max }$, at time $t=41$ ms. $A-E$ : responses for $2 \mathrm{AZs}$, with variable separation between centers of AZs: $\infty(A), 300 \mathrm{~nm}(B), 200 \mathrm{~nm}(C), 100 \mathrm{~nm}(D)$, and $50 \mathrm{~nm}(E)$. Scales $-X:(-250,+250 \mathrm{~nm})$ by $Y:(-130,+130 \mathrm{~nm})$. Vertical: $(0,700$ $\mu \mathrm{M})$. computations. This may also apply to the dense body situated in the middle of an AZ, the composition of which is unknown. The dense body may be composed of proteins that are a barrier to $\mathrm{Ca}^{2+}$ diffusion or may act as another immobile buffer, possibly having many binding sites. This may have effects on $\left[\mathrm{Ca}^{2+}\right]_{i}$ near the $\mathrm{Ca}_{\mathrm{v}}$ channels (Stern 1992). One of the effects of mobile buffer (with small molecular weight, thus a faster diffusion coefficient) is to facilitate $\left[\mathrm{Ca}^{2+}\right]_{\mathrm{i}}$ diffusion; thus, because we did not include mobile $\mathrm{Ca}^{2+}$ buffer, our results are conservative.

If tortuosity were implemented in the computational preparation as a reduction of $D_{\mathrm{Ca}}$ to, say, $0.5 D_{\mathrm{Ca}}$, this would be approximately equivalent to a situation in which only one half of the cross-sectional area of each volume element is open to a diffusing $\mathrm{Ca}^{2+}$ ion (Winslow et al. 1994b). Thus the present results may be an underestimation of the possible interaction of close AZs.

In general, the present model provides a first approach to evaluating possible interaction between A7s, but it is not complete, because the effects of tortuosity, $\mathrm{Ca}^{2+}$ pumps, and mobile buffers have not been included. The effects of these factors cannot be accurately evaluated from currently available data, but they would likely increase AZ interaction. The present model provides a conservative view of this interaction.

\section{Anatomy and physiology}

From the present work, the hypothesis arises that the probability of neurotransmitter release at a synapse may be enhanced when two $\Lambda \mathrm{Zs}$ are close together. We measured the actual direct line separation distances between neighboring AZs in reconstructions of excitatory motor neuron varicosities. A representative axonal varicosity possesses $20-40$ synapses, each of which has 0-5 AZs. On average, each AZ contains 18 putative channels (Govind et al. 1994), 13 of which we estimated to be $\mathrm{Ca}_{\mathrm{V}}$ channels. We found that in synapses with more than one $\mathrm{AZ}$, there is a range of separation distances between AZs; this can be as little as $50 \mathrm{~nm}$. Because AZs can be as large as $160 \mathrm{~nm}$ diam, AZs with centers separated by $<160 \mathrm{~nm}$ will combine their $\left[\mathrm{Ca}^{2+}\right]_{i}$ responses to produce spatial enhancement of $\left[\mathrm{Ca}^{2+}\right]_{i}$. The computational results supported this proposition. Spatial enhancement of $\left[\mathrm{Ca}^{2+}\right]_{i}$ could serve to release more neurotransmitter, depending on how many $\mathrm{Ca}_{\mathrm{V}}$ channels participate (this may fluctuate from trial to trial around the mean value) and on the $\left[\mathrm{Ca}^{2+}\right]_{i}$ needed to effect release of a vesicle. Thus the distribution of $\mathrm{AZ}$ separation distances may provide an anatomic basis for the well-characterized nonuniformity in probability of neurotransmitter release at crayfish terminals (Cooper et al. 1995b; Hatt and Smith 1976; Wojtowciz et al. 1991, 1994).

Recently, the $\mathrm{Ca}^{2+}$-binding protein synaptotagmin, thought to be a putative $\mathrm{Ca}^{2+}$ sensor for evoked release, has been shown to be present in crayfish motor neurons (Cooper et al. 1996). Considering that there may be an inhomogeneous distribution of $\mathrm{Ca}^{2+}$-binding proteins and that there is variation in synaptic structural complexity, one can expect that release would not be uniform for each synapse.

The statistical nature of transmitter release at crustacean neuromuscular junctions has been extensively studied ( $\mathrm{Du}-$ 

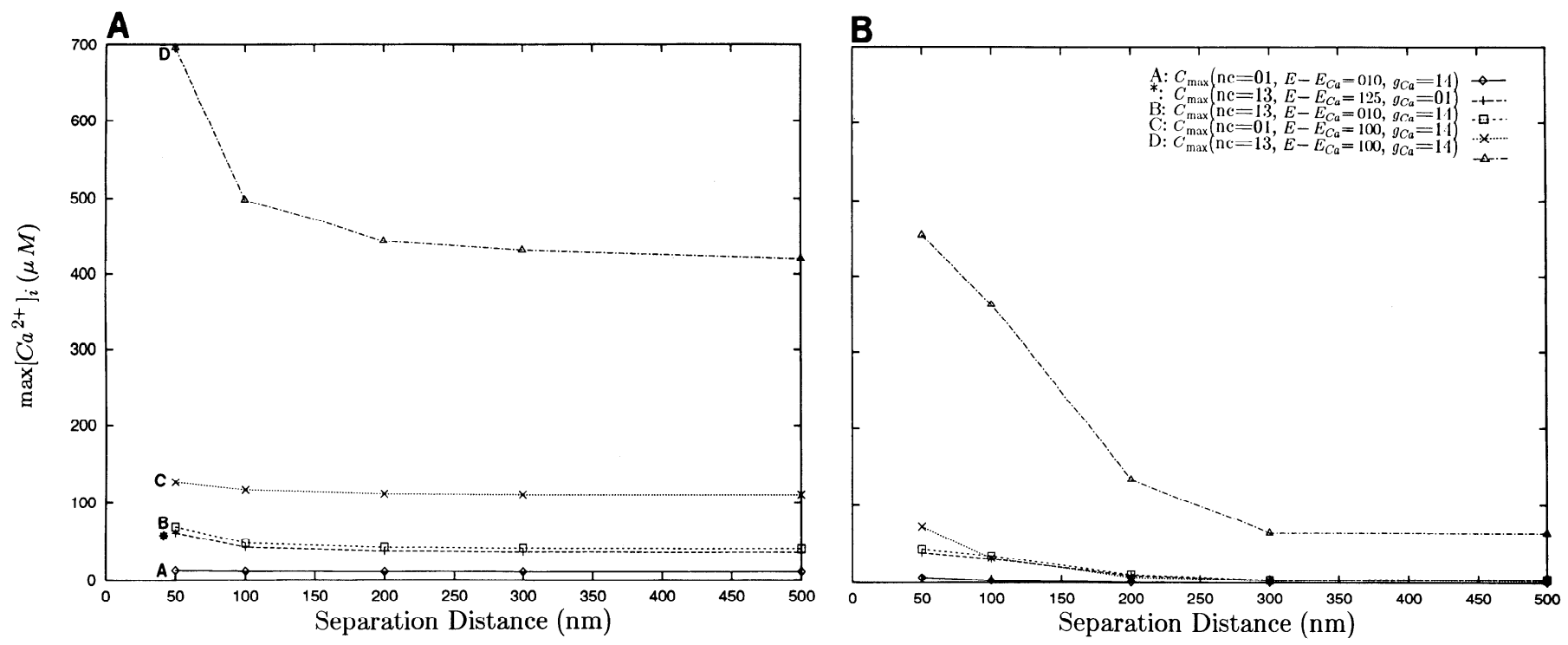

FIG. 12. Effect of AZ separation distance on the overall maximum of $\left[\mathrm{Ca}^{2+}\right]_{\mathrm{i}}$ per $\mathrm{AZ}$ and at the midpoint between the AZs vs. separation distance as in Figs. 10 and 11. Included for comparison (*) is the result for 13 channels open, $E-$ $E_{\mathrm{Ca}}=-125 \mathrm{mV}$, and $g_{\mathrm{Ca}}=1 \mathrm{pS}$. Each point represents the overall $\left|\mathrm{Ca}^{2+}\right|_{\mathrm{i}}$ maximum for each separation distance. $A$ : overall maximum of $\left[\mathrm{Ca}^{2+}\right]_{\mathrm{i}}$ vs. separation distance for $A-D . B$ : maximum $\left[\mathrm{Ca}^{2+}\right]_{\mathrm{i}}$ at midpoint between the AZs vs. separation distance for $A-D$. $C_{\max }$, maximum $\left[\mathrm{Ca}^{2+}\right]_{\mathrm{i}}$ over $X, Y$, and time; nc, number of channels; $E-E_{\mathrm{Ca}}=-10 \mathrm{mV}$ (peak of test pulse); $E-E_{\mathrm{Ca}}=-100 \mathrm{mV}$ (tail of test pulse).

del and Kuffler 1961; Parnas et al. 1982; Wernig 1972; Wojtowicz and Atwood 1986; Zucker 1974), but only recently have structural correlates been proposed for the same terminal region in which recordings were obtained (Cooper et al. 1995a; Wojtowicz et al. 1994). For the crayfish opener motor axon, it is clear that at low frequencies of stimulation, few quanta are released even though many small synapses occur in the terminal. Evidently, the probability of release is very low for most of these synapses, but the results from binomial statistical treatments suggest that a few have a higher probability of release (Johnson and Wernig 1971; Wojtowicz et al. 1994). The present study suggests that synapses with a higher probability of release may be those with two or more closely spaced AZs. Such synapses (a small fraction of the total observed on a terminal ) may represent the anatomic correlate of the number of release sites (quantal parameter $n$ ) observed at low stimulation frequencies (Wojtowicz et al. 1994). Values for $n$ at low frequencies are similar to the number of pairs of very closely spaced AZs. At higher frequencies of stimulation, background $\mathrm{Ca}^{2+}$ builds up (Delaney et al. 1989), and this may enhance AZ interactions because of increased binding with immobile buffer and the resultant further spread of free $\mathrm{Ca}^{2+}$. Mobile buffers, if present, would accentuate this effect. Interaction of more distant AZs would be promoted as more $\mathrm{Ca}^{2+}$ accumulates; this would give the nerve terminal an additional mechanism for grading synaptic output with frequency.

The low probability of release inferred for most synapses of this system may arise from the small number of $\mathrm{Ca}_{\mathrm{V}}$ channels opened by an action potential. It is not known what fraction of the total $\mathrm{Ca}_{\mathrm{v}}$ channels in the crayfish terminal is normally opened by an action potential, or how many need to be opened to have a quantal unit of neurotransmitter reliably released. It is apparent that the effectiveness of AZ interaction depends strongly on the number of $\mathrm{Ca}_{\mathrm{v}}$ channels opened at an AZ (Fig. 12). It has been suggested (Stanley 1993) that $\mathrm{Ca}^{2+}$ influx through a single open channel may be sufficient to induce vesicle-mediated release in chick ciliary ganglion. In contrast, Sugimori et al. (1994) calculated that in the squid presynaptic nerve terminal, more $\mathrm{Ca}^{2+}$ ions are required to cause vesicle release. These calculated differences in the number of $\left[\mathrm{Ca}^{2+}\right]_{i}$ ions that enter the nerve terminal as a prerequisite for the release of a single vesicle could be highly susceptible to differences in buffering ability and rate constants in different synaptic preparations. This is well worth investigating as a factor influencing synaptic transmission in different neurons.

Another uncertainty is the $\left[\mathrm{Ca}^{2+}\right]_{\mathrm{i}}$ actually needed at a critical site for evoked release. The relative importance of $\mathrm{Ca}^{2+}$ entry at an adjacent AZ would be dependent on the concentration of $\mathrm{Ca}^{2+}$ effective in causing release. It is apparent that a relatively low increase in the general background of $\left[\mathrm{Ca}^{2+}\right]_{i}$ enhances release (Delaney et al. 1989) even though it does not directly evoke much release. Thus it is possible that even a small additional increment of $\mathrm{Ca}^{2+}$ arriving from an adjacent $\mathrm{AZ}$ could enhance release probability for the synapse. Despite several uncertainties, the hypothesis of AZ interaction remains a viable alternative for nonuniform recruitment of synapses on a single nerve terminal.

We acknowledge and appreciate the detailed work in producing the EM sections and 3D reconstructions by L. Marin and the freeze-fracture photographs by J. Pearce. We are grateful to M. Ilegstrom-Wojtowicz, A. Shayan, and B. Gargach for technical assistance.

The experimental work was supported by a Canadian Medical Research Council Grant to H. L. Atwood, a Canadian Network Centres of Excellence Fellowship to R. L. Cooper, and a Natural Sciences and Engineering Research Council Grant to C. K. Govind. The theoretical studies were supported by a Natural Sciences and Engineering Research Council Grant to J. L. Winslow. 
Address for reprint requests: R. L. Cooper or J. L. Winslow, Physiology Dept., University of Toronto, Toronto, Ontario M5S-1A8, Canada.

Received 14 July 1995; accepted in final form 28 November 1995.

\section{REFERENCES}

Araque, A., Clarac, F., And Buño, W. P-type $\mathrm{Ca}^{2+}$ channels mediate excitatory and inhibitory synaptic transmitter release in crayfish muscle. Proc. Natl. Acad. Sci. USA 91: 4224-4228, 1994.

ATwOoD, H. L. AND COOPER, R. L. Assessing ultrastructure in crustacean and insect neuromuscular junctions. J. Neurosci. Methods. In press.

ATwood, H. L., COOPER, R. L., AND WoJTOwicz, J. M. Non-uniformity and plasticity of quantal release at crustacean motor nerve terminals. In: Molecular and Cellular Mechanisms of Neurotransmitter Release, edited by L. Stjärne, P. Greengard, S. Grillner, T. Hökfelt, and D. Ottoson. New York: Raven, 1994, p. 363-382.

ATwood, H. L., Govind, C. K., AND Jahromi, S. S. Excitatory synapses of blue crab gastric mill muscles. Cell Tissue Res. 177: 145-158, 1977.

ATwOOD, H. L. AND MARIN, L. Ultrastructure of synapses with different transmitter-releasing characteristics on motor axon terminals of a crab, Hyas areneas. Cell Tissue Res. 231: 103-115, 1983.

Augustine, G. J., Adler, E. M., AND Charlton, M. P. The calcium signal for transmitter secretion from presynaptic nerve terminals. Ann. NY Acad. Sci. 635: 365-381, 1991.

Augustine, G. J. AND ChaRlton, M. P. Calcium dependence of presynaptic calcium current and post-synaptic response at the squid giant synapse. J. Physiol. Lond. 381: 619-640, 1986.

Augustine, G. J., Charlton, M. P., AND Smith, S. J. Calcium entry and transmitter release at voltage-clamped nerve terminals of squid. J. Physiol. Lond. 367: 163-181, 1985.

Augustine, G. J., Charlton, M. P., AND Smith, S. J. Calcium action in synaptic transmitter release. Annu. Rev. Neurosci. 10: 633-693, 1987.

Augustine, G. J. AND NEHER, E. Calcium requirements for secretion in bovine chromaffin cells. J. Physiol. Lond. 450: 247-271, 1992.

Blundon, J. A., Wright, S. N., Brodwick, M. S., AND BitTNER, G. D. Residual free calcium is not responsible for facilitation of neurotransmitter release. Proc. Natl. Acad. Sci. USA 90: 9388-9392, 1993.

Blundon, J. A., Wright, S. N., Brodwick, M. S., AND BitTNER, G. D. Presynaptic calcium-activated potassium channels and calcium channels at a crayfish neuromuscular junction. J. Neurophysiol. 73: 178-189, 1995.

Cohen, M. W., Jones, O. T., AND ANGelides, K. J. Distribution of $\mathrm{Ca}^{2+}$ channels on frog motor nerve terminals revealed by fluorescent $\omega$-conotoxin. J. Neurosci. 11: 1032-1039, 1991.

CoOPER, R. L., HAMPSON, D. R., AND Atwood, H. L. Synaptotagmin-like expression in the motor nerve terminals of crayfish. Brain Res. 703: 214216, 1995.

COOPER, R. L., MARIN, L., AND ATwOOD, H. L. Synaptic differentiation of a single motor neuron: conjoint definition of transmitter release, presynaptic calcium signals, and ultrastructure. J. Neurosci. 15: 4209-4222, 1995a.

COOPER, R. L., STEWART, B. A., WoJTOWICZ, J. M., WANG, S., AND ATwooD, H. L. Quantal measurement and analysis methods compared for crayfish and Drosophila neuromuscular junctions, and rat hippocampus. J. Neurosci. Methods 61: 67-79, 1995b.

Cooper, R. L., Winslow, J. L., Govind, C. K., Pearce, J., Marin, L., AND ATwoov, H. L. Structural correlates of quantal parameters at crustacean neuromuscular junctions. Soc. Neurosci. Abstr. 20: 1339, 1994.

CoOper, R. L., Wojtowicz, J. M., AND Atwood, H. L. High- and lowoutput synapses of a single crustacean motor axon. Soc. Neurosci. Abstr. 19: $270,1993$.

CouteauX, R. Vesicules synaptiques et poches au niveau des “'zones active" de la jonction neuromusculaire. C. R. Acad. Sci. Ser. D Paris 271: 2346-2349, 1970.

CouteauX, R. AND PÉCOT-Dechavassine, M. Les zones spécialisées des membranes présynaptiques. C. $R$. Acad. Sci. Ser. D Paris 278: 291-293, 1974.

DELANEY, K. R., ZUCKER, R. S., AND TANK, D. W. Calcium in motor nerve terminals associated with posttetanic potentiation. J. Neurosci. 9: 35583567, 1989.

DiPolo, R. AND BEAuge, L. Calcium transport in excitable cells. In: Intracellular Calcium Regulation, edited by F. Bronner. New York: WileyLiss, 1990, p. 381-413.

Dreyer, F., PEPER, K., AKert, K., SANDri, C., AND MOOR, H. Ultrastructure of the 'active zone' in the frog neuromuscular junction. Brain Res. 62: 373-380, 1973.

DowLING, J. E. Synaptic organization of the frog retina: an electron microscopic analysis comparing the retinas of frogs and primates. Proc. $R$. Soc. Lond. B Biol. Sci. 170: 205-228, 1968.

Dudel, J. AND Kuffler, S. W. The quantal nature of transmission and spontaneous miniature potentials at the crayfish neuromuscular junction. J. Physiol. Lond. 155: 514-529, 1961.

Engstrom, H., Bergstrom, B., AND Ades, W. H. Macula utriculi and macula sacculi in the squirrel monkey. In: Inner Ear Studies, edited by W. H. Ades and H. Engstrom. Acta Otolarygol. Suppl. 301: 75-126, 1972.

FLOREY, E. AND CAHILL, M. A. The innervation pattern of crustacean skeletal muscle. Cell Tissue Res. 224: 527-541, 1982.

Fogelson, A. L. AND ZuCKER, R. S. Presynaptic calcium diffusion from various arrays of single channels. Biophys. J. 48: 1003-1017, 1985.

GARRAhan, P. J. AND REGA, A. F. Plasma membrane calcium pump. In: Intracellular Calcium Regulation, edited by F. Bronner. New York: Wiley-Liss, 1990, p. 271-303.

Govind, C. K., Pearce, J., Wottowicz, J. M., AND Atwood, H. L. "Strong" and "weak" synaptic differentiation in the crayfish opener muscle: structural correlates. Synapse 16: 45-58, 1994.

HatT, H. AND SMITH, D. O. Non-uniform probabilities of quantal release at the crayfish neuromuscular junction. J. Physiol. Lond. 259: 395-404, 1976.

HeUSER, J. E. AND REESE, T. S. Evidence for recycling of synaptic vesicle membrane during transmitter release at the frog neuromuscular junction. J. Cell Biol. 57: 315-344, 1973.

Heuser, J. E., ReESe, T. S., AND LANdis, D. M. D. Functional changes in frog neuromuscular junctions studied with freeze-fracture. I. Neurocytol. 3: 109-131, 1974.

HINDMARSH, A. C. LSODE and LSODI, two new initial value ordinary differential equation solvers. Assoc. Comp. Mach. SIGNUM Newsl. 15: $10-11,1980$.

Hodgkin, A. L. AND KeYNES, R. D. Movements of labelled calcium in squid giant axons. J. Physiol. Lond. 138: 253-281, 1957.

IsSA, N. P. AND HudsPETH, A. J. Clustering of $\mathrm{Ca}^{2+}$ channels and $\mathrm{Ca}^{2+}-$ activated $\mathrm{K}^{+}$channels at fluorescently labeled presynaptic active zones of hair cells. Proc. Natl. Acad. Sci. USA 91: 7578-7582, 1994.

JAHROMI, S. S. AND ATwOOD, H. L. Three-dimensional ultrastructure of the crayfish neuromuscular apparatus. J. Cell Biol. 63: 599-613, 1974.

JoHNSON, E. W. AND WERNIG, A. The binomial nature of transmitter release at the crayfish neuromuscular junction. J. Physiol. Lond. 218: 757-767, 1971.

KATZ, B. AND MiLEDI, R. The timing of calcium action during neuromuscular transmission. J. Physiol. Lond. 189: 535-544, 1967.

KATZ, B. AND MILEDI, R. The role of calcium in neuromuscular facilitation. J. Physiol. Lond. 195: 481-492, 1968.

LLINAS, R. R. Calcium and transmitter release in squid synapse. In: Society for Neuroscience Symposia: Approaches to the Cell Biology of Neurons, edited by W. M. Cowan and J. A. Ferrendelli. Bethesda, MD: Soc. Neurosci., 1977, vol. II, p. 139-160.

LlinAS, R., STEINBERG, I. Z., AND WALton, K. Presynaptic calcium currents and their relation to synaptic transmission: voltage clamp study in squid giant synapse and theoretical model for the calcium gate. Proc. Natl. Acad. Sci. USA 73: 2918-2922, 1976.

LlinAs, R., Steinberg, I. Z., AND WALTON, K. Relationship between presynaptic calcium current and postsynaptic potential in squid giant synapse. Biophys. J. 33: 323-352, 1981.

LLINAS, R. SUGIMORI, M., AND SILVER, R. B. Microdomains of high calcium concentration in a presynaptic terminal. Science Wash. DC 256: 677679, 1992.

MuALLEM, S. Calcium transport by resting and stimulated cells. In: Intracellular Calcium Regulation, edited by F. Bronner. New York: Wiley-Liss, 1990, p. 349-380.

NowyCKY, M. C. AND PINTER, J. M. Time courses of calcium and calciumbound buffers following calcium influx in a model cell. Biophys. J. 64: 77-91, 1993.

PapPas, G. D. AND WAXMAN, S. G. Synaptic fine structure: morphological correlates of chemical and electronic transmission. In: Structure and Function of Synapses, edited by G. D. Pappas and D. P. Purpura. New York: Raven, 1972, p. 1-44.

Parnas, H., Dudel, J., AND PARnas, I. Neurotransmitter release and its 
facilitation in crayfish. 1. Saturation kinetics of release, and of entry and removal of calcium. Pfluegers Arch. 393: 1-14, 1982.

Parnas, H. and Segel, L. A. Facilitation as a tool to study the entry of calcium and the mechanism of neurotransmitter release. Prog. Neurobiol. 32: $1-9,1988$.

Parsegian, V. A. Considerations in determining the mode of influence of calcium on vesicle-membrane interaction. In: Society for Neuroscience Symposia: Approaches to the Cell Biology of Neurons, edited by W. M. Cowan and J. A. Ferrendelli. Bethesda, MD: Soc. Neurosci., 1977, vol. II, p. $161-171$.

Peters, A., Palay, S. L., and Webster, H. De F. The Fine Structure of the Nervous System-The Cells and Their Processes. New York: Harper and Row, 1970.

PROPST, J. W. AND Ko, C. P. Correlations between active zone ultrastructure and synaptic function studied with freeze-fracture of physiologically identified neuromuscular junctions. J. Neurosci. 7: 3654-3664, 1987.

Pumplin, D. W., Reese, T. S., And Llinas, R. Are the presynaptic membrane particles the calcium channels? Proc. Natl. Acad. Sci. USA 78: 7210-7213, 1981.

ReEves, J. P. Sodium-calcium exchange. In: Intracellular Calcium Regulation, edited by F. Bronner. New York: Wiley-Liss, 1990, p. 305-347.

RoBERTs, W. M. Spatial calcium buffering in saccular hair cells. Nature Lond. 363: 74-76, 1993.

ROBERTS, W. M. Localization of calcium signals by a mobile calcium buffer in frog saccular hair cells. J. Neurosci. 14: 3246-3262, 1994.

RoberTs, W. M., Jacobs, R. A., AND HudsPeth, A. J. Colocalization of ion channels involved in frequency selectivity and synaptic transmission at presynaptic active zones of hair cells. J. Neurosci. 10: 3664-3684, 1990.

Roberts, W. M., Jacobs, R. A., And Hudspeth, A. J. The hair cell as a presynaptic terminal. Ann. NY Acad. Sci. 635: 221-233, 1991.

Robitaille, R., Adler, E. M., and Charlton, M. P. Strategic location of calcium channels at transmitter release sites of frog neuromuscular synapses. Neuron 5: 773-779, 1990.

Robitaille, R., Garcia, M. L., Kaczorowski, G. J., and Charlton, M. P. Functional colocalization of calcium and calcium-gated potassium channels in control of transmitter release. Neuron 11: 645-655, 1993.

SimON, S. M. AND LLINAS, R. R. Compartmentalization of the submembrane calcium activity during calcium influx and its significance in transmitter release. Biophys. J. 48: 485-498, 1985.

SMITH, C. A. Innervation pattern of the cochlea. The internal hair cell. Ann. Otol. Rhinol. Laryngol. 70: 504-527, 1961.

Smitil, S. J., Buchanan, J., Osses, L. R., Charlton, M. P., and AuGUSTINE, G. J. The spatial distribution of calcium signals in squid presynaptic terminals. J. Physiol. Lond. 472: 573-593, 1993.

SpoenduIn, H. Ultrastructure and peripheral innervation pattern of the receptor in relation to the first coding of the acoustic message. In: Hearing Mechanisms in Vertebrates, edited by A. V. S. de Reuck and J. Knight. London: Churchill, 1968, p. 89-119.

Stani.ey, E. F. Single calcium channels and acetylcholine release at a presynaptic nerve terminal. Neuron 11: 1007-1011, 1993.

STERN, M. D. Buffering of calcium in the vicinity of a channel pore. Cell Calcium 13: 183-192, 1992.

Sugimori, M., Lang, E. J., Silver, R. B., and Llinas, R. High-resolution measurement of the time course of calcium-concentration microdomains at squid presynaptic terminals. Biol. Bull. 187: 300-303, 1994.
Usowicz, M. M., Sugimori, M., Ciicrksey, B., And Llinas, R. P-type calcium channels in the somata and dendrites of adult cerebellar Purkinje cells. Neuron 9: 1185-1199, 1992.

Walrond, J. P., Govind, C. K., ANd Huestis, S. E. Two structurà adaptations for regulating transmitter release at lobster neuromuscular synapses. J. Neurosci. 13: 4831-4845, 1993.

Walrond, J. P. And Reese, T. S. Structure of axon terminals and active zones at synapses on lizard twitch and tonic muscle fibers. J. Neurosci. 5: 1118-1131, 1985.

WERnIG, A. The effects of calcium and magnesium on statistical release parameters at the crayfish neuromuscular junction. J. Physiol. Lond. 226: 761-768, 1972.

WinsLow, J. L. Analysis and numerical solution of the dendrite equation with synapses applied to cochlear ncurons. Prog. Neurobiol. 34: 91-105, 1990.

WinsLow, J. L. Apparent diffusion coefficient estimation errors from using ratio of bound to unbound $\mathrm{Ca}^{2+}$ In: The Neurobiology of Computation, edited by J. Bower. Norwell, MA: Kluwer, 1995, p. 33-38.

Winslow, J. L., BJERKNes, M., AND Cheng, H. Three-dimensional reconstruction of biological objects using a graphics engine. Comp. Biomed. Res. 20: 583-602, 1987.

Winslow, J. L., Cooper, R. L., Govind, C. K., Pearce, J., Marin, L., AND ATwood, H. L. Close presynaptic active zones may enhance facilitation. Soc. Neurosci. Abstr. 20: 1339, 1994a.

Winslow, J. L., DufFy, S. N., ANd Charlton, M. P. Homosynaptic facilitation of transmitter release in crayfish is not affected by mobile calcium chelators: implications for the residual ionized calcium hypothesis from electrophysiological and computational analyses. J. Neurophysiol. 72: $1769-1793,1994 b$.

WoJtowicz, J. M. AND ATwood, H. L. Long-term facilitation alters transmitter releasing properties at the crayfish neuromuscular junction. $J$. Neurophysiol. 55: 484 498, 1986.

Wojtowicz, J. M., Marin, L., AND Atwood, H. L. Activity-induced changes in synaptic release sites at the crayfish neuromuscular junction. J. Neurosci. 14: 3688-3702, 1994.

Wojtowicz, J. M., Smith, B. R., AND Atwood, H. L. Activity-dependent recruitment of silent synapses. Ann. NY Acad. Sci. 627: 169-179, 1991.

Wright, S. N., BRodwick, M. S., AND BitTNER, G. D. Presynaptic calcium current and neurotransmitter release at voltage clamped terminals of crayfish neuromuscular junctions. Soc. Neurosci. Abstr. 20: 900, 1994.

YAMADA, W. M. AND ZuCKer, R. S. Time course of transmitter release calculated from simulations of a calcium diffusion model. Biophys. $J$. 61: 671-682, 1992.

ZHou, Z. AND NeHER, E. Mobile and immobile calcium buffers in bovine adrenal chromaffin cells. J. Physiol. Lond. 469: 245-273, 1993.

ZUCKER, R. S. Crayfish neuromuscular facilitation activated by constant presynaptic action potentials and depolarizing pulses. J. Physiol. Lond. 241: 69-89, 1974.

ZUCKER, R. S. Short-term synaptic plasticity. Annu. Rev. Neurosci. 12: 1331, 1989.

Zucker, R. S., Delaney, K. R., Mulkey, R., And Tank, D. W. Presynaptic calcium in transmitter release and posttetanic potentiation. Ann. NY Acad. Sci. 635: 191-207, 1991.

ZUCKER, R. S. AND FogELSON, A. L. Relationship between transmitter release and presynaptic calcium influx when calcium enters through discrete channels. Proc. Natl. Acad. Sci. USA 83: 3032-3036, 1986. 